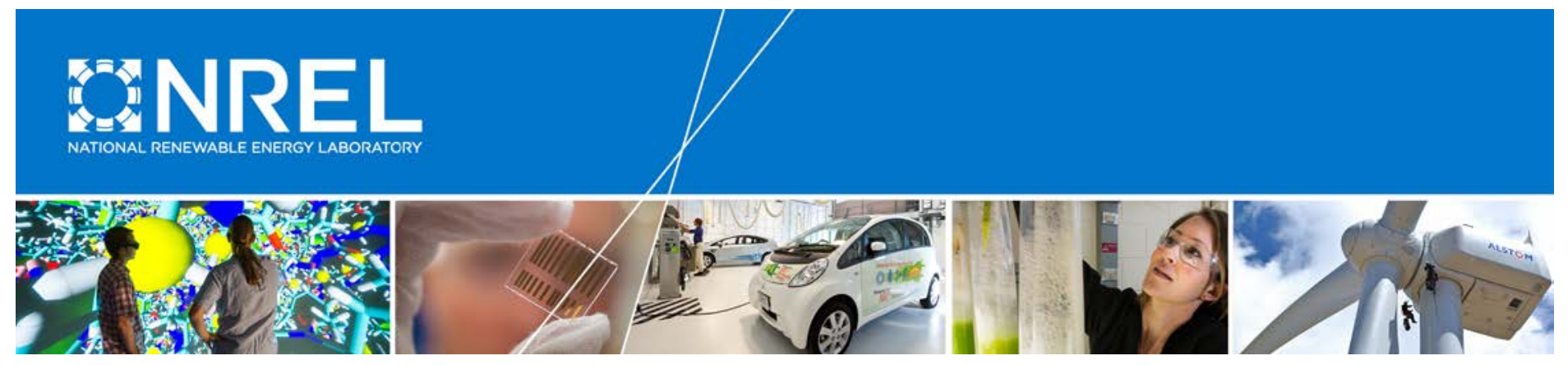

\title{
Consumer Views on Transportation and Advanced Vehicle Technologies
}

\author{
Mark Singer \\ National Renewable Energy Laboratory
}

NREL is a national laboratory of the U.S. Department of Energy Office of Energy Efficiency \& Renewable Energy Operated by the Alliance for Sustainable Energy, LLC

This report is available at no cost from the National Renewable Energy Laboratory (NREL) at www.nrel.gov/publications.

Technical Report

NREL/TP-5400-64840

September 2015

Contract No. DE-AC36-08GO28308 


\title{
Consumer Views on Transportation and Advanced Vehicle Technologies
}

\author{
Mark Singer \\ National Renewable Energy Laboratory
}

Prepared under Task No. VTP2.2700

NREL is a national laboratory of the U.S. Department of Energy Office of Energy Efficiency \& Renewable Energy Operated by the Alliance for Sustainable Energy, LLC

This report is available at no cost from the National Renewable Energy Laboratory (NREL) at www.nrel.gov/publications.

National Renewable Energy Laboratory 15013 Denver West Parkway Golden, CO 80401

303-275-3000 • www.nrel.gov

\section{Technical Report} NREL/TP-5400-64840

September 2015

Contract No. DE-AC36-08GO28308 


\title{
NOTICE
}

This report was prepared as an account of work sponsored by an agency of the United States government. Neither the United States government nor any agency thereof, nor any of their employees, makes any warranty, express or implied, or assumes any legal liability or responsibility for the accuracy, completeness, or usefulness of any information, apparatus, product, or process disclosed, or represents that its use would not infringe privately owned rights. Reference herein to any specific commercial product, process, or service by trade name, trademark, manufacturer, or otherwise does not necessarily constitute or imply its endorsement, recommendation, or favoring by the United States government or any agency thereof. The views and opinions of authors expressed herein do not necessarily state or reflect those of the United States government or any agency thereof.

This report is available at no cost from the National Renewable Energy Laboratory (NREL) at www.nrel.gov/publications.

Available electronically at SciTech Connect http:/www.osti.gov/scitech

Available for a processing fee to U.S. Department of Energy and its contractors, in paper, from:

\author{
U.S. Department of Energy \\ Office of Scientific and Technical Information \\ P.O. Box 62 \\ Oak Ridge, TN 37831-0062 \\ OSTI http://www.osti.gov \\ Phone: 865.576.8401 \\ Fax: 865.576.5728 \\ Email: reports@osti.gov
}

Available for sale to the public, in paper, from:

\author{
U.S. Department of Commerce \\ National Technical Information Service \\ 5301 Shawnee Road \\ Alexandra, VA 22312 \\ NTIS http://www.ntis.gov \\ Phone: 800.553 .6847 or 703.605 .6000 \\ Fax: 703.605.6900 \\ Email: orders@ntis.gov
}




\section{Consumer Views Quick Facts}

The following findings are based on a series of selected historical studies that cover consumer attitudes toward a wide range of transportation-related topics.

\section{Fuel Economy Perceptions}

- $56 \%$ of respondents in 2007 considered fuel economy during their latest vehicle purchase.

- $76 \%$ of respondents in 2007 expressed satisfaction with their current vehicles' fuel economy.

- In 2011 gas prices averaged $\$ 3.63$ per gallon; respondents expected prices to range from $\$ 3.40$ to $\$ 5.40$ per gallon over the following 5 years.

- In 2011 respondents on average stated that under a worst-case scenario a vehicle with a U.S. Environmental Protection Agency rating of 25 miles per gallon would achieve only 18 miles per gallon.

- $77 \%$ of respondents in 2011 required a 5 mile per gallon or greater fuel economy rating difference between two vehicles for fuel economy to impact their final purchase decisions.

- In comparison to other vehicle attributes, the importance of fuel economy for respondents rose steadily in the 1990s and the early 2000s but has been flat to declining since 2011.

\section{Future Technology Options}

- Respondents most often selected electricity as the best alternative to gasoline in comparison to hydrogen and ethanol between 2000 and 2011.

- Respondents most often selected ethanol as the worst alternative to gasoline in comparison to hydrogen and electricity between 2000 and 2011.

- A fuel's perceived availability, affordability, and positive environmental impacts were given as top reasons for choosing a fuel as the best alternative to gasoline between 2000 and 2011 .

\section{Ethanol Perceptions}

- $69 \%$ of respondents in 2006 stated that they did not know anything about E85.

- $66 \%$ of respondents in 2006 , once provided information about E85, stated a willingness to drive at least 2 miles out of their way to purchase it.

- $57 \%$ of respondents in 2006 , once provided information about E85, were willing to pay an increase in fuel costs of $10 \%$ or higher in order to use it.

\section{Plug-in Electric Vehicle Sentiments}

- $\quad 57 \%$ of respondents in 2006 believed they could plug in a vehicle at home.

- $56 \%$ of respondents in 2006 believed a plug-in hybrid electric vehicle could be a good fit for their households.

- $24 \%$ of respondents in 2006 were considering small sedans for their next vehicle purchases.

- $68 \%$ of respondents in 2006 stated a willingness to consider a plug-in electric vehicle with an incremental cost.

- $47 \%$ of respondents in 2013 said plug-in electric vehicles were just as good as or better than gasoline vehicles.

\section{Willingness to Pay for Efficiency}

- New and used car purchasers reported an equal willingness to pay an increased upfront vehicle cost in exchange for undiscounted fuel cost savings over the life of the vehicle.

- A fuel-efficient vehicle technology would require an undiscounted payback period of 1 to 1.5 years for $50 \%$ of respondents to state a willingness to pay an increased upfront vehicle cost. 


$\begin{array}{ll}\text { Acronyms } & \\ \text { DOE } & \text { U.S. Department of Energy } \\ \text { E85 } & \text { high-level ethanol-gasoline blend containing 51\%-83\% ethanol } \\ \text { EV } & \text { electric vehicle } \\ \text { FFV } & \text { flex-fuel vehicle } \\ \text { HEV } & \text { hybrid electric vehicle } \\ \text { mpg } & \text { miles per gallon } \\ \text { NREL } & \text { National Renewable Energy Laboratory } \\ \text { ORC } & \text { Opinion Research Corporation } \\ \text { PEV } & \text { plug-in electric vehicle } \\ \text { PHEV } & \text { plug-in hybrid electric vehicle }\end{array}$




\section{Acknowledgments}

This work has been supported by the U.S. Department of Energy's (DOE's) Vehicle Technologies Office. Additional support came from the National Renewable Energy Laboratory, which is a national laboratory of the DOE's Office of Energy Efficiency and Renewable Energy operated by the Alliance for Sustainable Energy, LLC.

The author would like to thank advanced vehicle technology deployment subject matter experts including Alicia Birky, Aaron Brooker, Stacy Davis, David Greene, Zhenhong Lin, Changzheng Liu, Dawn Manley, Michael Nicholas, Aymeric Rousseau, Dan Santini, Tom Stephens, Joann Zhou, Caley Johnson, George Mitchell, and Margo Melendez who provided helpful insights into how vehicle technologies might be accepted into the marketplace.

The author would like to specifically thank Jake Ward at DOE's Vehicle Technologies Office, without whom the resources necessary for this research would not be available.

All judgments in the final analytic methodologies and interpretations are the responsibility of the author. 


\section{Table of Contents}

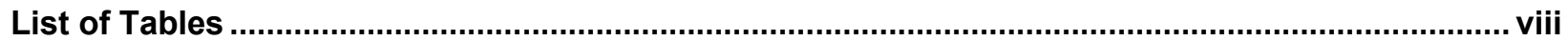

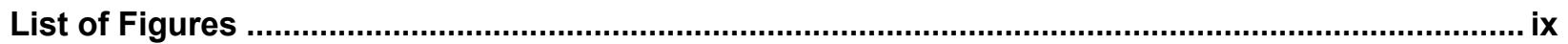

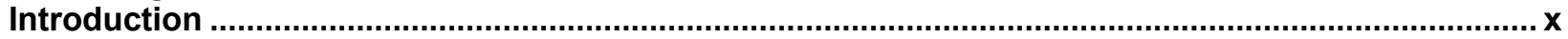

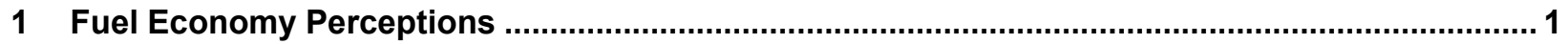

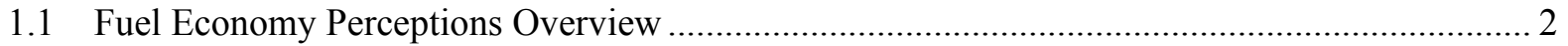

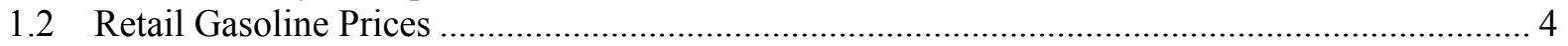

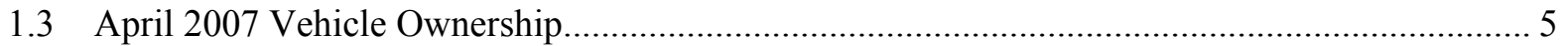

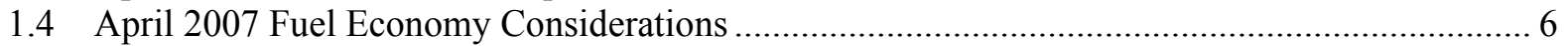

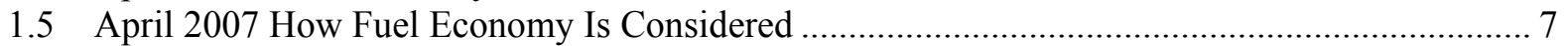

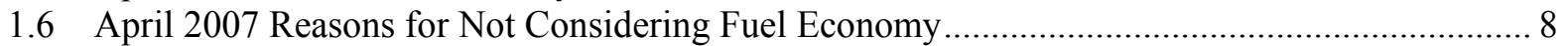

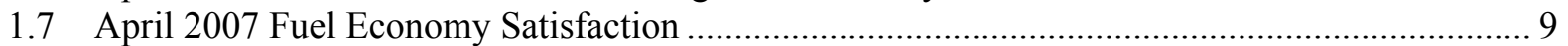

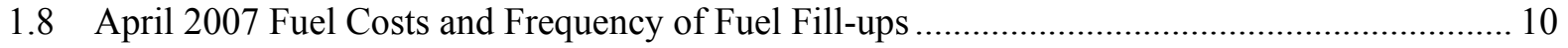

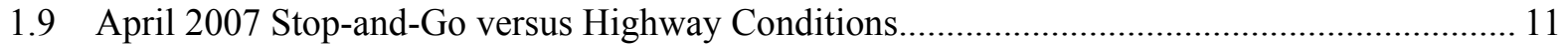

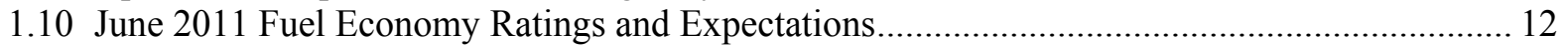

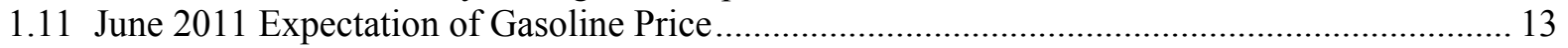

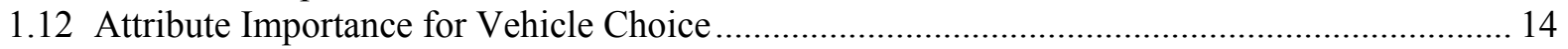

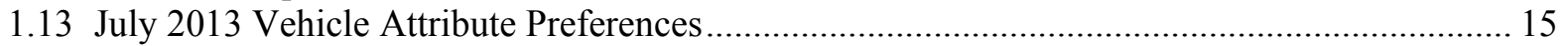

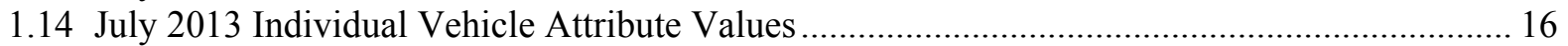

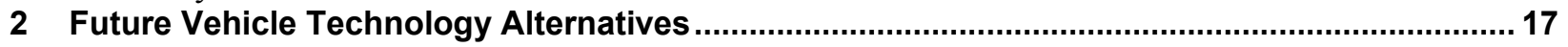

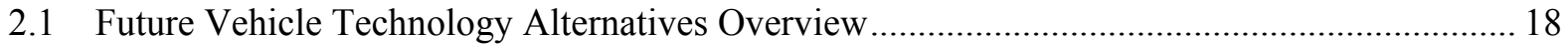

2.2 December 2005 Factors that Impact Consumer Interest in Vehicle Fuel Types ........................ 19

2.3 The Best Replacement for Gasoline and Reasons for Electricity ............................................. 20

2.4 Reasons Ethanol Is the Best Replacement for Gasoline....................................................... 21

2.5 Reasons Hydrogen Is the Best Replacement for Gasoline ..................................................... 22

2.6 The Worst Replacement for Gasoline and Reasons for Electricity .......................................... 23

2.7 Reasons Ethanol Is the Worst Replacement for Gasoline ........................................................ 24

2.8 Reasons Hydrogen Is the Worst Replacement for Gasoline ..................................................... 25

2.9 August 2007/2008 Hybrid and Diesel versus Gasoline Vehicles...........................................26

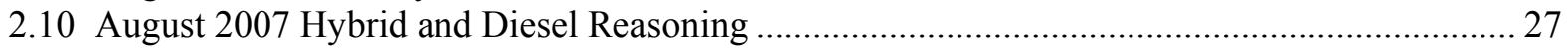

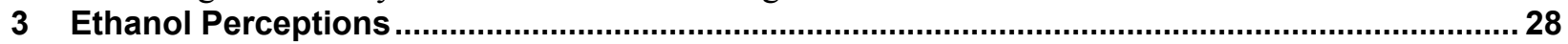

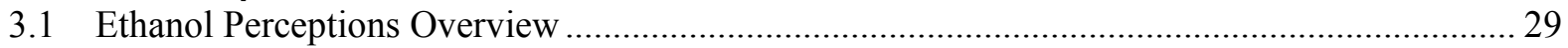

3.2 September 2006 E85 Awareness and Positive E85 Opinions ……........................................ 30

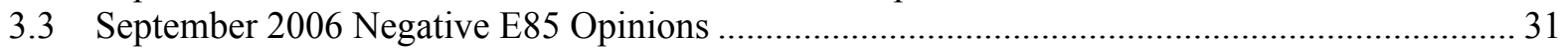

3.4 September 2006 Perceived E85 Availability and FFV Awareness ........................................... 32

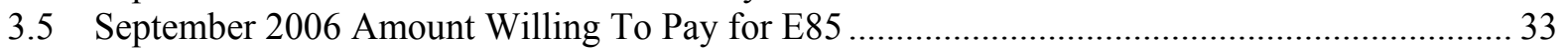

3.6 September 2006 Distance Willing To Drive for E85 …........................................................... 34

3.7 September 2006 Willingness To Pay More for E85 versus Gasoline ....................................... 35

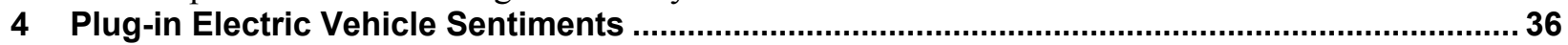

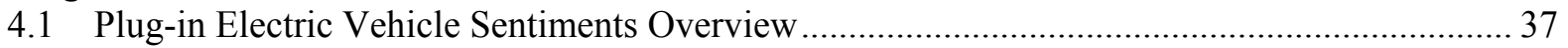

4.2 June 2006 Type of Vehicle for Next Planned Purchase and Willingness To Purchase a Hybrid

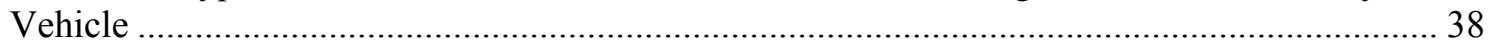

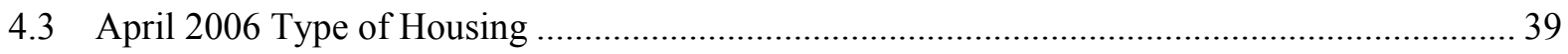

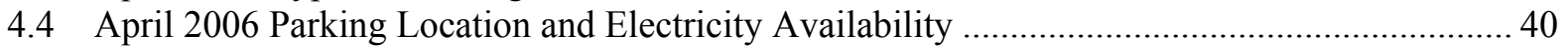

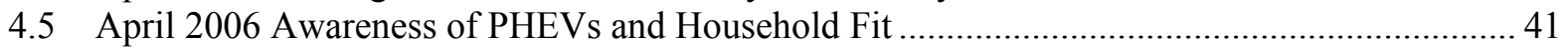

4.6 July 2013 Plug-in Electric Vehicle Awareness and Exposure .................................................. 42

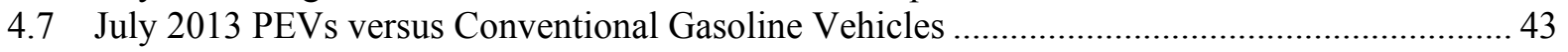

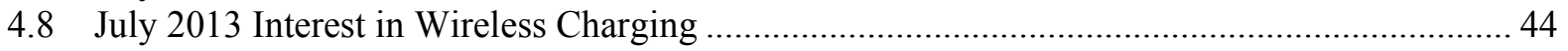

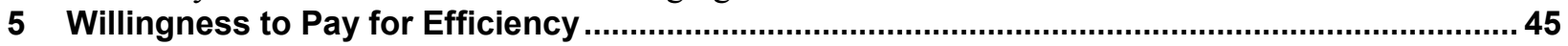

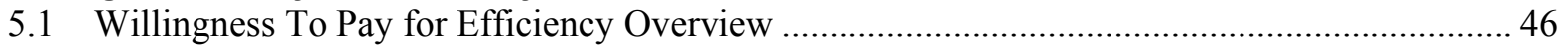

5.2 June 2011 Incremental Cost Willing To Pay for Increased Fuel Efficiency .............................. 47 
5.3 June 2011 Fuel Cost Savings Required To Pay More for Higher Fuel Economy

5.4 April 2012 Incremental Cost Willing To Pay for More Efficient Vehicle (Revised Amounts).. 49

5.5 April 2012 Fuel Cost Savings Required To Pay More for Higher Fuel Economy (Revised Amounts).

5.6 January 2013 Likelihood of Purchasing a New versus a Used Vehicle...

5.7 January 2013 Fuel Cost Savings Required To Pay More for Higher Fuel Economy (New versus Used Vehicle Purchasers).

5.8 Implied Payback Periods for Willingness To Pay More for Higher Fuel Economy ................... 53

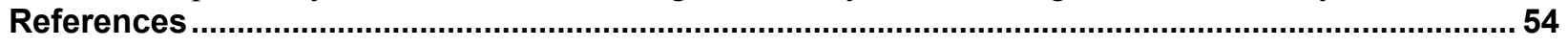




\section{List of Tables}

Table 1. April 2007 Question 3: Terms for the Rate at Which Vehicles Use Fuel.................................... 6

Table 2. April 2007 Question 4: Consideration of Fuel Economy for Vehicle Purchase ............................. 6

Table 3. April 2007 Question 5: How Fuel Economy Is Considered ....................................................... 7

Table 4. April 2007 Question 6: Reasons Fuel Economy Not Considered.............................................. 8

Table 5. April 2007 Question 7: Satisfaction with Fuel Economy ......................................................... 9

Table 6. June 2011 Question 2: Impact of Fuel Economy When Comparing Vehicles for Purchase ........ 12

Table 7. Most Important Vehicle Attribute in Choice of Next Vehicle ................................................... 14

Table 8. July 2013 Question 2: Rate Importance of Vehicle Attributes ................................................... 16

Table 9. December 2005: Factors That Impact Purchase of a New Vehicle Fuel Technology .................. 19

Table 10. Reasons Electricity Would Be the Best Replacement for Gasoline...........................................2 20

Table 11. Reasons Ethanol Would Be the Best Replacement for Gasoline .............................................. 21

Table 12. Reasons Hydrogen Would Be the Best Replacement for Gasoline .......................................... 22

Table 13. Reasons Electricity Would Be the Worst Replacement for Gasoline ....................................... 23

Table 14. Reasons Ethanol Would Be the Worst Replacement for Gasoline ........................................... 24

Table 15. Reasons Hydrogen Would Be the Worst Replacement for Gasoline.........................................25

Table 16. Comparison of Hybrid and Diesel Vehicles with Conventional Gasoline Vehicles................... 26

Table 17. Reasons for Selecting a Conventional Gasoline Vehicle over a Hybrid or Diesel Vehicle........ 26

Table 18. Reasons for Selecting a Diesel Vehicle over a Hybrid or Conventional Gasoline Vehicle........ 27

Table 19. Reasons for Selecting a Hybrid Vehicle over a Conventional Gasoline or Diesel Vehicle........ 27

Table 20. September 2006 Question 1: E85 Comparison to Gasoline...................................................... 30

Table 21. September 2006 Question 2: Reasons for Positive E85 Sentiments ........................................ 30

Table 22. September 2006 Question 3: Reasons for Negative E85 Sentiments .................................... 31

Table 23. September 2006 Question 4: Perception of E85 Availability .................................................. 32

Table 24. September 2006 Question 5: E85 Vehicle Awareness............................................................ 32

Table 25. September 2006 Question 8: Willingness to Pay More for E85 versus Gasoline....................... 35

Table 26. June 2006 Question 1: Type of Vehicle for Next Planned Purchase ......................................... 38

Table 27. June 2006 Question 2: Willingness to Purchase a Hybrid Vehicle............................................ 38

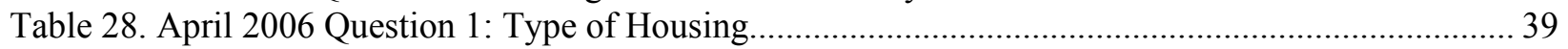

Table 29. April 2006 Question 2A: Locations Where Vehicles are Parked ............................................. 40

Table 30. April 2006 Question 3A: Availability of Electrical Outlet Where Vehicle is Parked ................ 40

Table 31. April 2006 Question 2B: Awareness of PHEVs ................................................................... 41

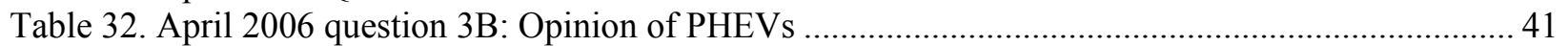

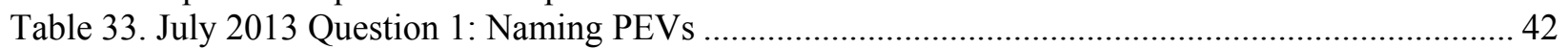

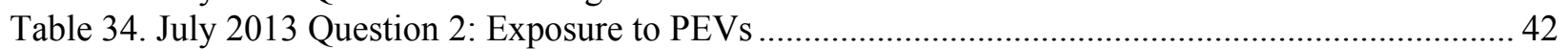

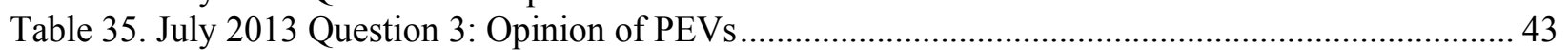

Table 36. July 2013 Question 4: Interest in Wireless Charging .......................................................... 44

Table 37. January 2013 Question 1: Likelihood of Purchasing a New versus a Used Vehicle .................. 51 


\section{List of Figures}

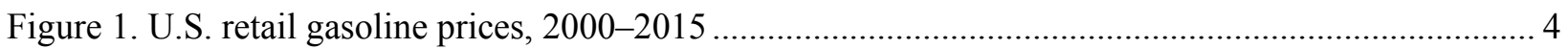

Figure 2. April 2007 question 1: New vehicle purchases ............................................................. 5

Figure 3. April 2007 question 2: Operating vehicles in household......................................................... 5

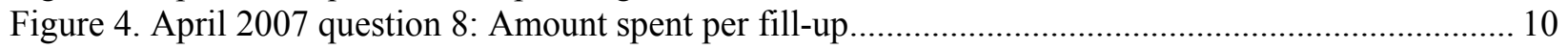

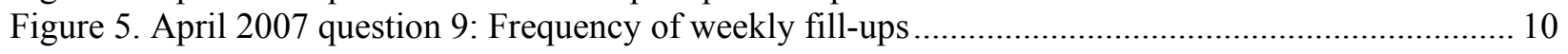

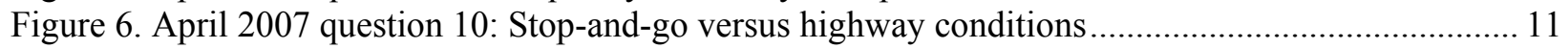

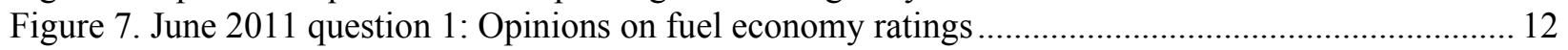

Figure 8. June 2011 question 3: Expectation of highest gasoline price ................................................. 13

Figure 9. June 2011 question 4: Expectation of lowest gasoline price ................................................ 13

Figure 10. Actual national weekly gasoline price distribution since June 2011 ...................................... 13

Figure 11. July 2013 question 1: Most important attribute in choosing a vehicle .................................. 15

Figure 12. July 2013 question 2: Rate importance of vehicle attributes ................................................ 16

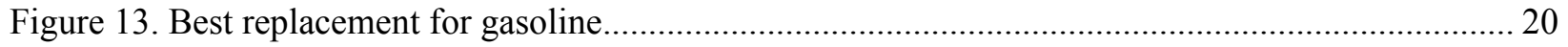

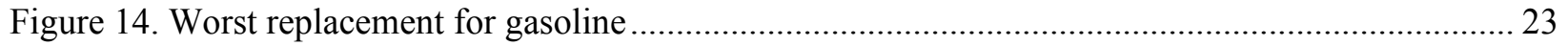

Figure 15. September 2006 question 6: Amount willing to pay for E85 ............................................. 33

Figure 16. September 2006 question 7: Distance willing to drive for E85 ......................................... 34

Figure 17. July 2013 Question 3: PEV Exposure and PEV Opinions ................................................... 43

Figure 18. July 2013 question 5: Willingness to pay more for PEVs ...................................................... 44

Figure 19. June 2011 question 1: Incremental cost willing to pay for increased fuel efficiency ............... 47

Figure 20. June 2011 question 2: Fuel cost savings required to pay more for higher efficiency................ 48

Figure 21. April 2012 question 1: Incremental cost willing to pay for increased fuel efficiency............... 49

Figure 22. April 2012 question 2: Fuel cost savings required to pay more for higher efficiency.............. 50

Figure 23. January 2013: Fuel cost savings required to pay more for higher efficiency ..........................5 52

Figure 24. Compiled results: Implied undiscounted payback periods .................................................... 53 


\section{Introduction}

Vehicle manufacturers, U.S. Department of Energy (DOE) laboratories, universities, private researchers, and organizations from around the globe are pursuing advanced vehicle technologies that aim to reduce the consumption of petroleum in the form of gasoline and diesel. In order to make these technologies most appealing to the marketplace, they must take consumer sentiment into account. This report details study findings of broad American public sentiments toward issues that surround advanced vehicle technologies and is supported by the DOE's Vehicle Technologies Office in alignment with its mission to develop and deploy these technologies to improve energy security, provide mobility flexibility, reduce transportation costs, and increase environmental sustainability.

Understanding and tracking consumer sentiments can influence the prioritization of development efforts by identifying barriers to and opportunities for the broad acceptance of new technologies. Predicting consumer behavior toward developing technologies and products is inherently inexact. A person's stated preference in an interview about a hypothetical setting often does not match his or her revealed preference, which is demonstrated in an actual decision-making situation (Kane and Wasi 2013). This difference makes tracking actual consumer actions ultimately more valuable in understanding potential behavior. However, when developing technologies are not yet available and actual behaviors cannot be tracked, stated preferences provide some insight into how consumers may react in new circumstances. In this context this report provides an additional source to validate other data and a new resource when no data are available.

This report summarizes study data captured from December 2005 through June 2015 relevant to Vehicle Technologies Office research efforts at the time of the studies. The report broadly covers respondents' sentiments about vehicle fuel economy, future vehicle technology alternatives, ethanol as a vehicle fuel, plug-in electric vehicles (PEVs), and willingness to pay for vehicle efficiency. This report represents a renewed effort to publicize study findings and make consumer sentiment data available to researchers, policy-makers, and the public. Planned reports will follow that provide detailed data from new studies that target the primary challenges to and opportunities for advanced vehicle technology deployment. The effort continually refines study content to maintain and improve the relevance and validity of results.

Most of the data presented in this report are the results of interviews conducted by the Opinion Research Corporation (ORC) for the National Renewable Energy Laboratory (NREL). The ORC CARAVAN studies are conducted via telephone with randomly selected telephone numbers. Starting with a December 2012 study, all studies included in this report use a dual-frame sampling design in which the sample is drawn from independent landline and cell phone sample frames. All studies are based on responses from individuals across the country who are 18 years old and older. Response samples are weight-adjusted to better ensure the sample reflects the general U.S. population. The CARAVAN studies rely on ORC's weighting mechanism, which pulls from data reported in the National Health Interview Survey and the U.S. Census Bureau's Current Population Survey. When ORC study data are presented, the specific ORC study number is noted along with the year of the study and the study sample size. Sample sizes are typically 1,000 respondents. 
In many instances throughout this report, the response percentages in tables and figures do not sum to exactly $100 \%$, because the raw data are rounded. For the same reason, summary data points called out in the body of the report may not match the results that were attained by summing data from the tables and figures. 


\section{Fuel Economy Perceptions}

\section{Contents}

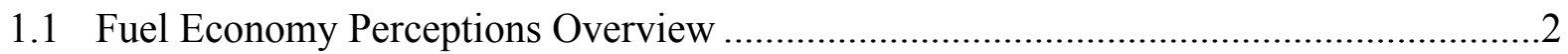

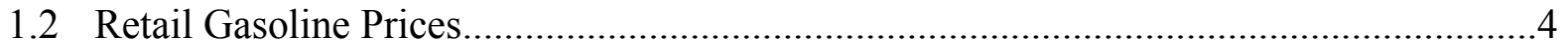

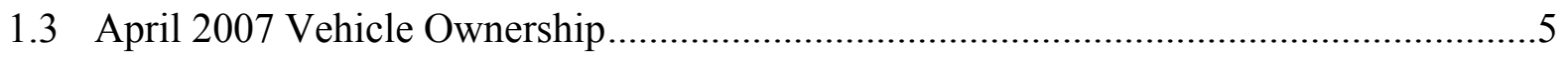

1.4 April 2007 Fuel Economy Considerations ....................................................................6

1.5 April 2007 How Fuel Economy Is Considered ...............................................................

1.6 April 2007 Reasons for Not Considering Fuel Economy ................................................

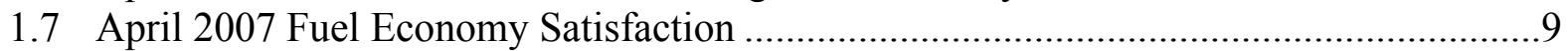

1.8 April 2007 Fuel Costs and Frequency of Fuel Fill-ups ...................................................10

1.9 April 2007 Stop-and-Go versus Highway Conditions......................................................11

1.10 June 2011 Fuel Economy Ratings and Expectations.....................................................12

1.11 June 2011 Expectation of Gasoline Price ................................................................13

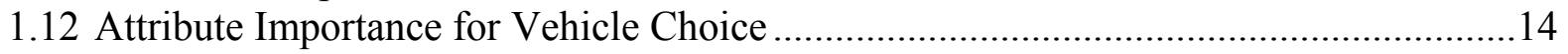

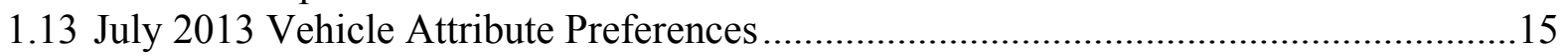

1.14 July 2013 Individual Vehicle Attribute Values .............................................................16 


\subsection{Fuel Economy Perceptions Overview}

Studies have investigated how consumers perceive their current rate of petroleum consumption, or fuel economy, and how they may expect fuel economy to change in the future. These findings help to define how advanced vehicle technologies that seek to reduce the rate of petroleum consumption align with past and current consumer and market interests. For drivers to use less petroleum, they will need to (1) adjust their driving behaviors to be more fuel efficient, (2) purchase vehicles that are more fuel efficient, or (3) purchase vehicles that rely on an alternative fuel technology. In order to reduce fuel consumption, drivers will need to be aware of vehicle fuel economies, feel that their vehicles' fuel economy is important, and then make fuel efficient decisions.

Perhaps the most obvious effects of fuel economy for a vehicle owner are the costs associated with using fuel. This section begins with an overview of gasoline prices in the United States since 2000. Two studies detailed in this report investigated vehicle fuel economy: one in April 2007 and one in June 2011. In April 2007 gasoline prices were about \$3 per gallon and in the middle of a rise that would not stop until the 2008 financial collapse. The June 2011 study took place after the price had rebounded from the collapse and would remain near $\$ 3.50$ per gallon until 2014.

These studies coincided with updates to the U.S. Environmental Protection Agency's fuel economy ratings and how those ratings are displayed on new vehicle labels. In 2008 the U.S. Environmental Protection Agency updated the way vehicle fuel economy was rated to more closely reflect real-world driving conditions (DOE 2008). The ratings largely resulted in vehicles being rated with lower fuel economies than previously. In 2011 the U.S. Environmental Protection Agency updated the vehicle label (DOE 2011) to incorporate additional information about fuel costs associated with a particular vehicle, comparisons of the vehicle's fuel economy with that of other vehicles, and environmental impacts of the vehicle's fuel economy.

The 2007 study showed that fuel economy was considered by a majority of respondents (56\%) during their latest vehicle purchases. Those that did not consider fuel economy stated this was because they considered a specific vehicle type or other characteristics to have been more important than fuel efficiency. Overall $76 \%$ of respondents reported satisfaction with their vehicles' fuel economy.

The June 2011 study looked at how fuel economy ratings impacted respondent decision making and how respondents thought gasoline prices might change in the future. Respondents reported pessimism about whether vehicles could actually achieve the fuel economy displayed on the U.S. Environmental Protection Agency fuel economy label. Respondents reported they expected to achieve the rating only under the best-case scenario and that under the worst-case scenario a vehicle rated at 25 miles per gallon ( $\mathrm{mpg}$ ) would achieve less than $18 \mathrm{mpg}$. This lack of trust in the rating may partly explain why a large majority $(77 \%)$ would require a difference in fuel economy of $5 \mathrm{mpg}$ or more to make a vehicle purchase decision based on fuel economy. The study results do not necessarily reflect that the 2008 label update did not improve the alignment of vehicle rating with actual driver fuel economy, because not all respondents would have recently purchased vehicles and had experience with the new label. 
At the time of the 2011 study respondents on average expected gasoline prices to range from a low of $\$ 3.40$ to a high of $\$ 5.40$ per gallon over the following 5 years. Respondents seemed to be expressing a belief that gasoline prices would increase from the actual cost of $\$ 3.63$ at the time of the study. However, in the time since the study, prices remained near $\$ 3.50$ before dropping significantly in 2014.

Fuel economy is only one of many attributes consumers consider when purchasing vehicles. Surveys dating back to 1980 have asked respondents to choose the most important vehicle attribute during the purchase process. The trends show the relative importance of fuel economy rose steadily in the 1990s and into the early 2000s but has been flat to declining in recent years. The importance of fuel economy remained high during the gasoline price drop near the time of the 2008 financial collapse (see Figure 1), but fuel economy importance appeared to have dropped in 2014 when gasoline prices dropped significantly. A 2013 study further expanded the set of attributes respondents could consider and ultimately showed that although fuel economy was important, a broad array of attributes including dependability, price, and safety were just as or more important than fuel economy in the final purchase decision. 


\subsection{Retail Gasoline Prices}

U.S. retail gasoline prices, while volatile, rose throughout the 2000s until the global financial collapse in 2008. Prices then rebounded close to previous highs in 2011, when they remained relatively stable before falling throughout 2014 . The decline is believed to be due in part to lower economic activity as world markets continue to adjust to the 2008 financial collapse, increased U.S. oil production, steady OPEC oil production, and increased efficiencies in fuel use. Studies of consumer perceptions of fuel economy were completed during the time period in Figure 1 in April 2007 when prices were climbing and again in June 2011 when prices had rebounded from the 2008 drop.

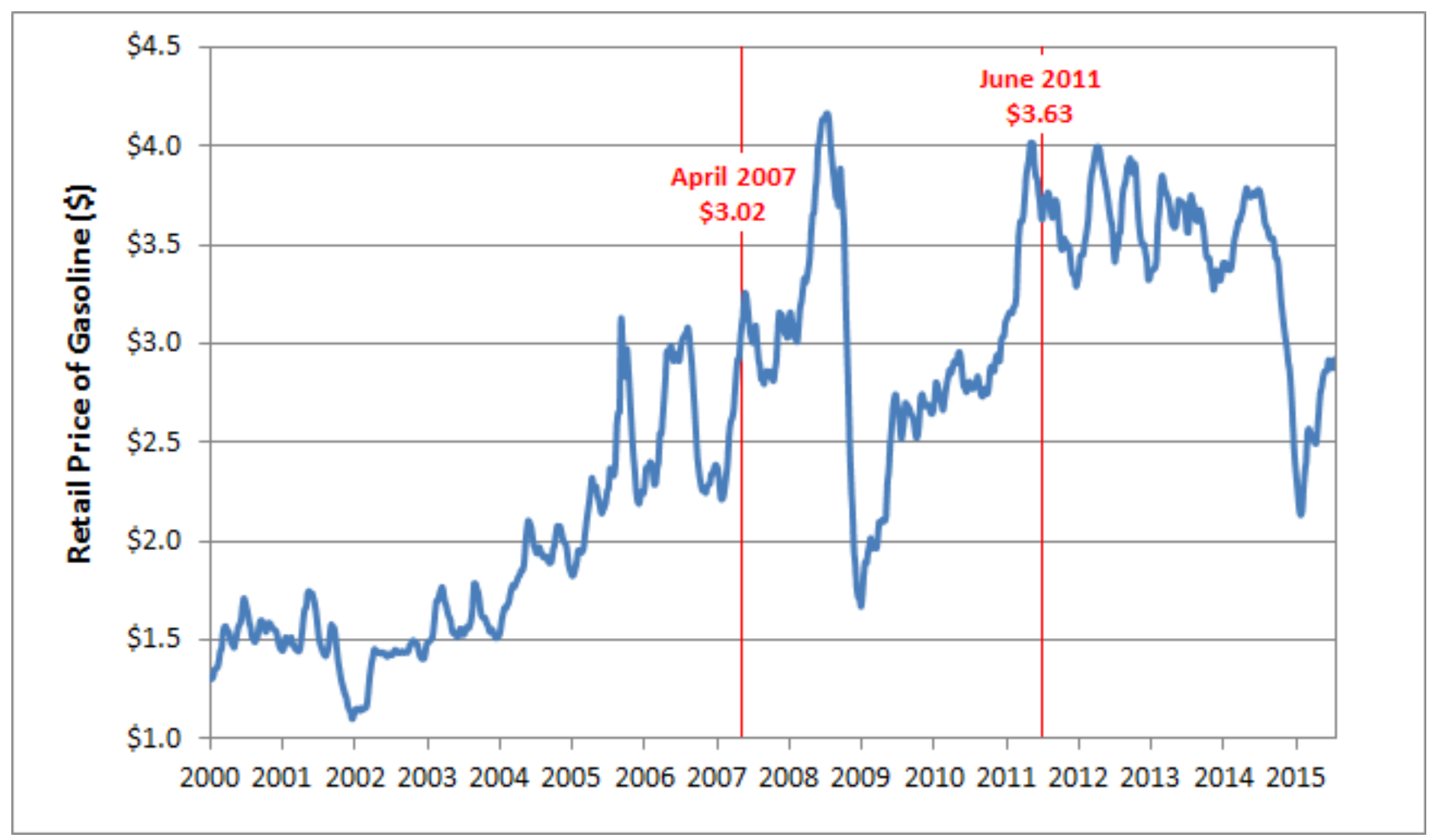

Figure 1. U.S. retail gasoline prices, $2000-2015$

\section{Sources:}

EIA. 2015. "Gasoline and Diesel Fuel Update." U.S. Energy Information Administration, accessed August 7, 2015: http://www.eia.gov/petroleum/gasdiesel/.

The Economist. 2014. "Why the Oil Price Is Falling." The Economist, accessed August 7, 2015: http://www.economist.com/blogs/economist-explains/2014/12/economist-explains-4. 


\subsection{April 2007 Vehicle Ownership}

The April 2007 study began by asking respondents how many vehicles they had recently purchased and how many vehicles their household currently owned. In the 7-year period from January 2000 through April 2007, the mean number of new car purchases by respondents was 1.1 . The mean number of cars owned by respondent households was 2 , and $65 \%$ of households reported owning one or two cars.

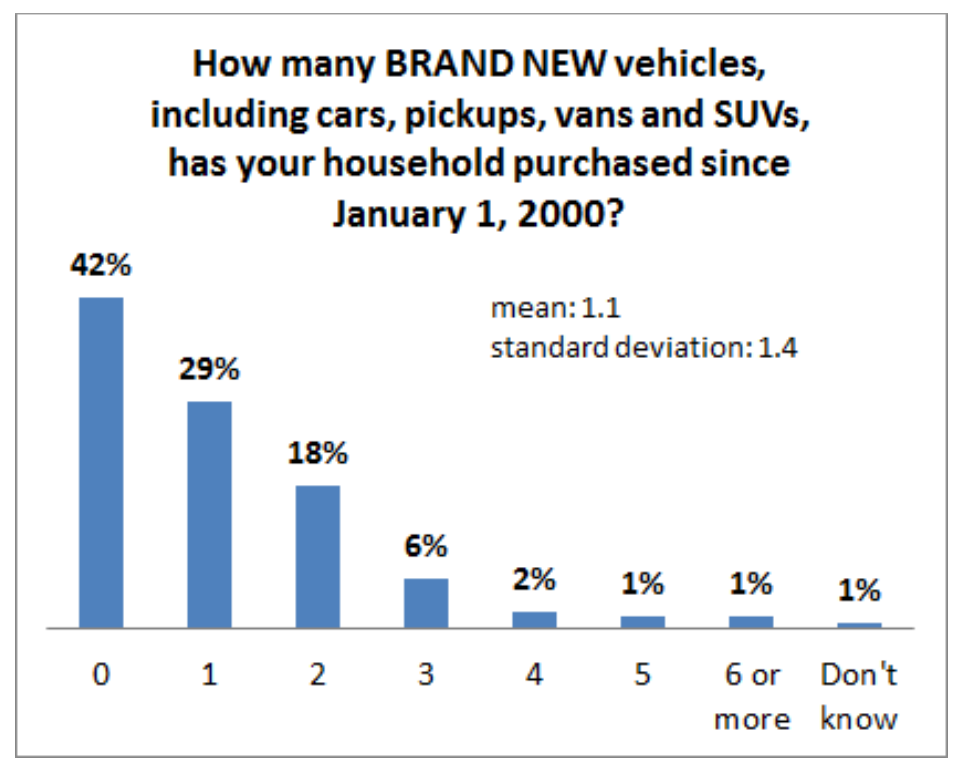

Figure 2. April 2007 question 1: New vehicle purchases

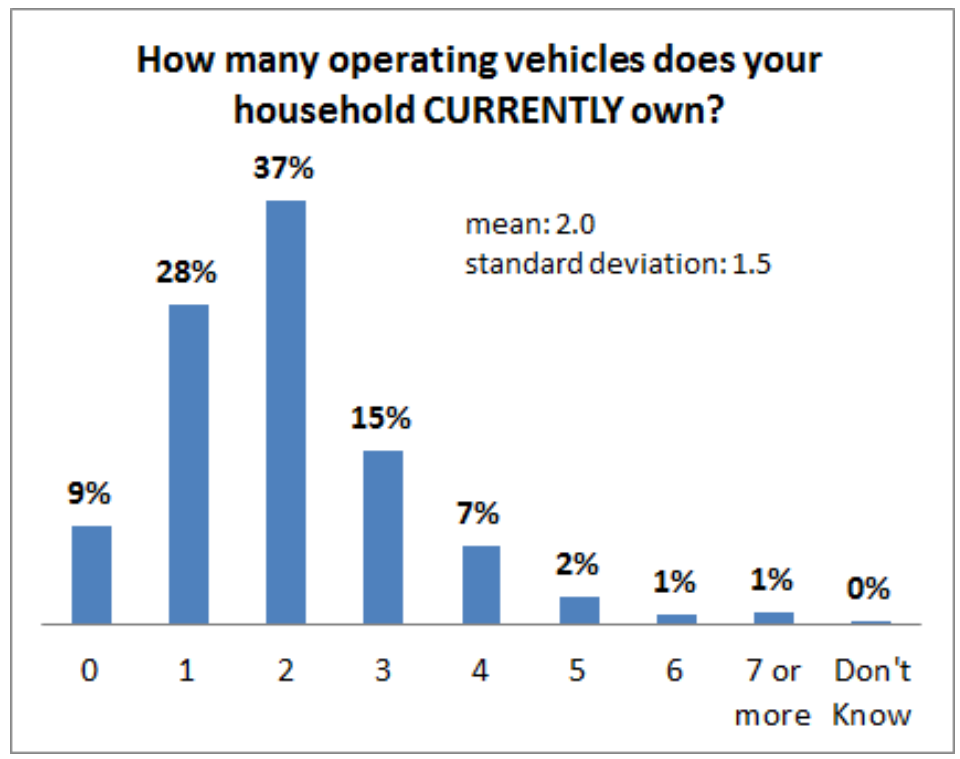

Figure 3. April 2007 question 2: Operating vehicles in household

\section{Source:}

ORC for NREL (2007), Study No. 716159, N=1,000. 


\subsection{April 2007 Fuel Economy Considerations}

In the April 2007 study respondents identified "mpg" and "Gas mileage" as the terms they most commonly used when talking about the rate at which vehicles use fuel.

\begin{tabular}{|l|r|}
\hline $\begin{array}{l}\text { What do you call the number of miles a vehicle } \\
\text { gets on a gallon of fuel? Is it called ... }\end{array}$ & $\begin{array}{l}\text { Percent of } \\
\text { Responses }\end{array}$ \\
\hline Fuel economy & $8 \%$ \\
\hline Gas mileage & $36 \%$ \\
\hline mpg & $48 \%$ \\
\hline Other & $1 \%$ \\
\hline None of these & $1 \%$ \\
\hline Don't know & $6 \%$ \\
\hline
\end{tabular}

Table 1. April 2007 Question 3: Terms for the Rate at Which Vehicles Use Fuel

\section{Source:}

ORC for NREL (2007), Study No. 716159, N=1,000.

Fifty-six percent of respondents in the April 2007 study indicated that they considered fuel economy at the time of their latest vehicle purchases. A smaller percentage (37\%) stated they did not consider fuel economy.

\begin{tabular}{|l|r|}
\hline $\begin{array}{l}\text { Considering the last vehicle you bought, did you consider } \\
\text { fuel economy when comparing different vehicles? }\end{array}$ & $\begin{array}{l}\text { Percent of } \\
\text { Responses }\end{array}$ \\
\hline Yes & $56 \%$ \\
\hline No & $37 \%$ \\
\hline Never purchased a car & $6 \%$ \\
\hline Don't know & $2 \%$ \\
\hline
\end{tabular}

Table 2. April 2007 Question 4: Consideration of Fuel Economy for Vehicle Purchase

\section{Source:}

ORC for NREL (2007), Study No. 716159, N=1,000. 


\subsection{April 2007 How Fuel Economy Is Considered}

In April 2007, 56\% of respondents stated they did consider fuel economy during their latest vehicle purchases. These respondents stated they took into account the fuel efficiency rating as well as vehicle and fuel costs associated with the vehicles.

\begin{tabular}{|l|r|}
\hline In what ways did you consider fuel economy? & $\begin{array}{r}\text { Percent of } \\
\text { Responses }\end{array}$ \\
\hline Vehicle mpg ratings & $54 \%$ \\
\hline Fuel cost savings and vehicle costs & $14 \%$ \\
\hline Characteristics of vehicle & $10 \%$ \\
\hline Type of vehicle & $7 \%$ \\
\hline Most important/One of the most important considerations & $4 \%$ \\
\hline Comparison of vehicles (unspecified) & $4 \%$ \\
\hline Environmental concerns & $3 \%$ \\
\hline Amount of distance traveled & $2 \%$ \\
\hline Carpooling/Using car less frequently & $2 \%$ \\
\hline Considered it but not a major factor & $1 \%$ \\
\hline I drive often/drive long distances & $1 \%$ \\
\hline Read manufacturers sticker info & $1 \%$ \\
\hline Research in magazines/ newspapers & $1 \%$ \\
\hline Other & $7 \%$ \\
\hline Don't know/No response & $8 \%$ \\
\hline
\end{tabular}

Table 3. April 2007 Question 5: How Fuel Economy Is Considered

\section{Source:}

ORC for NREL (2007), Study No. 716159, N=561.

\section{Note:}

Some responses were grouped under multiple reasons and therefore percentages do not sum to 100. Only respondents who answered in question 4 that they did consider fuel economy during their last vehicle purchases were asked question 5. 


\subsection{April 2007 Reasons for Not Considering Fuel Economy}

In April 2007, 37\% of respondents stated they did not consider fuel economy during their latest vehicle purchases. These respondents stated they were interested in a specific vehicle type or other characteristics of vehicles viewed as more important than fuel efficiency.

\begin{tabular}{|l|r|}
\hline $\begin{array}{l}\text { Why didn't you consider fuel economy in your last car } \\
\text { purchase? }\end{array}$ & $\begin{array}{r}\text { Percent of } \\
\text { Responses }\end{array}$ \\
\hline Type of vehicle & $21 \%$ \\
\hline Characteristics of vehicle & $12 \%$ \\
\hline Cost/Price & $12 \%$ \\
\hline Don't care/Not important/Not a priority & $11 \%$ \\
\hline Purchased in past & $9 \%$ \\
\hline Purchased for specific purpose & $7 \%$ \\
\hline Familiarity & $5 \%$ \\
\hline Someone else purchased the vehicle & $4 \%$ \\
\hline Just didn't think of it & $3 \%$ \\
\hline Don't drive often/long distances & $3 \%$ \\
\hline Don't own/drive a car & $1 \%$ \\
\hline Gas is less expensive & $1 \%$ \\
\hline Other & $8 \%$ \\
\hline Don't know/No response & $10 \%$ \\
\hline
\end{tabular}

Table 4. April 2007 Question 6: Reasons Fuel Economy Not Considered

\section{Source:}

ORC for NREL (2007), Study No. 716159, N=365.

\section{Note:}

Some responses were grouped under multiple reasons; therefore, percentages do not sum to 100. Only respondents who answered in question 4 that they did not consider fuel economy during their last vehicle purchases were asked question 6. 


\subsection{April 2007 Fuel Economy Satisfaction}

In April 2007 a strong majority (76\%) of respondents were satisfied with the fuel economy of their vehicles. Fifty-six percent of respondents in the same study had previously stated in question 4 that they had considered fuel economy at the time of their last purchases. A majority of respondents may have been voicing that although fuel economy is important, they did not need to improve their current fuel economy.

\begin{tabular}{|l|r|}
\hline $\begin{array}{l}\text { Are you satisfied with the fuel economy of the last } \\
\text { vehicle you bought? }\end{array}$ & $\begin{array}{r}\text { Percent of } \\
\text { Responses }\end{array}$ \\
\hline Yes & $76 \%$ \\
\hline No & $23 \%$ \\
\hline Don't know & $2 \%$ \\
\hline
\end{tabular}

Table 5. April 2007 Question 7: Satisfaction with Fuel Economy

\section{Source:}

ORC for NREL (2007), Study No. 716159, N=943.

Note:

Respondents who answered, "Never purchased a car" to question 4 were not asked question 7. 


\subsection{April 2007 Fuel Costs and Frequency of Fuel Fill-ups}

In April 2007 the mean reported cost per fuel purchase was \$37.30. Forty-one percent of respondents reported spending between $\$ 26$ and $\$ 40$. The mean number of fill-ups per week was 1.1 , and $89 \%$ of respondents filled up no more often than two times per week.

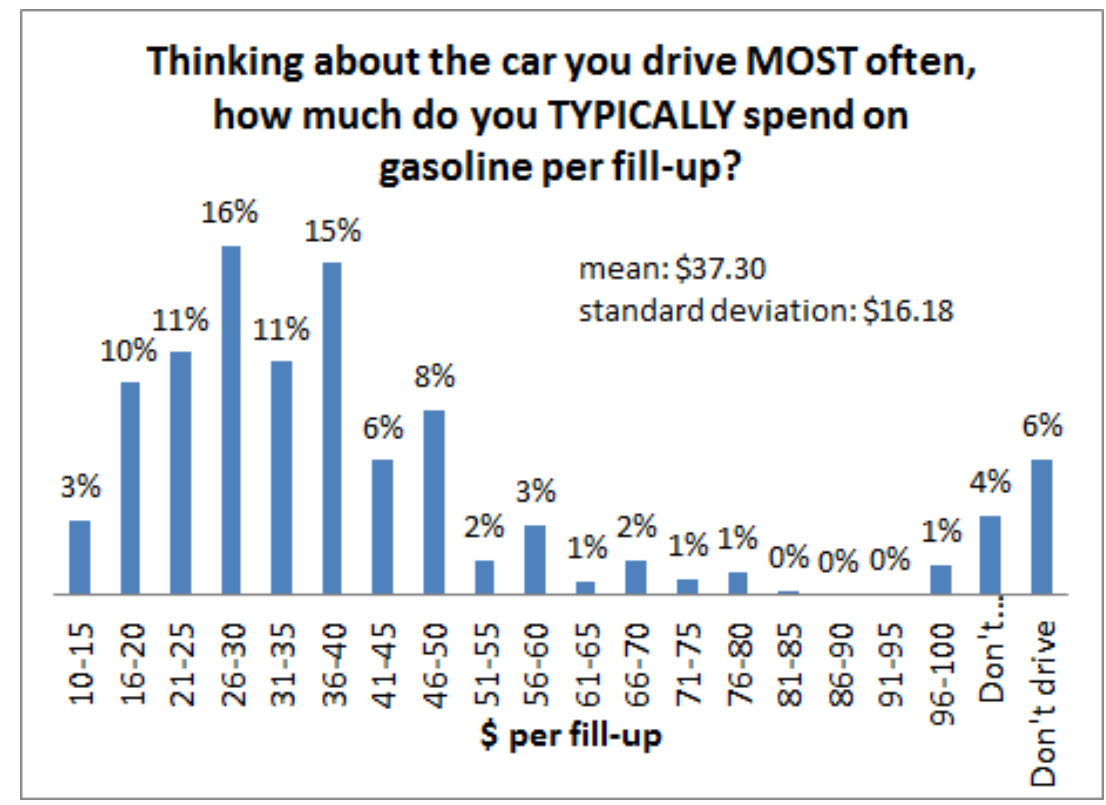

Figure 4. April 2007 question 8: Amount spent per fill-up

Source:

ORC for NREL (2007), Study No. 716159, N=1,000.

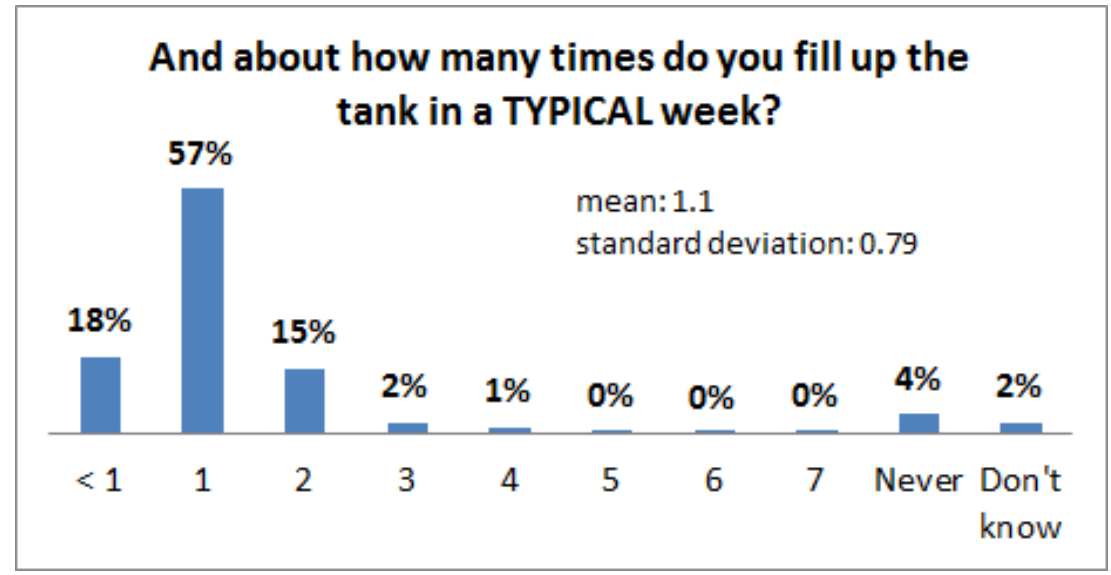

Figure 5. April 2007 question 9: Frequency of weekly fill-ups

\section{Source:}

ORC for NREL (2007), Study No. 716159, N=939.

Note: Respondents who answered, "Don't Drive" to question 8 were not asked questions 9 and 10 . 


\subsection{April 2007 Stop-and-Go versus Highway Conditions}

In April 2007 respondents reported a broad set of percentages of stop-and-go driving versus highway driving. The mean stop-and-go percentage was 54\%, indicating survey respondents drove slightly more in a stop-and-go setting.

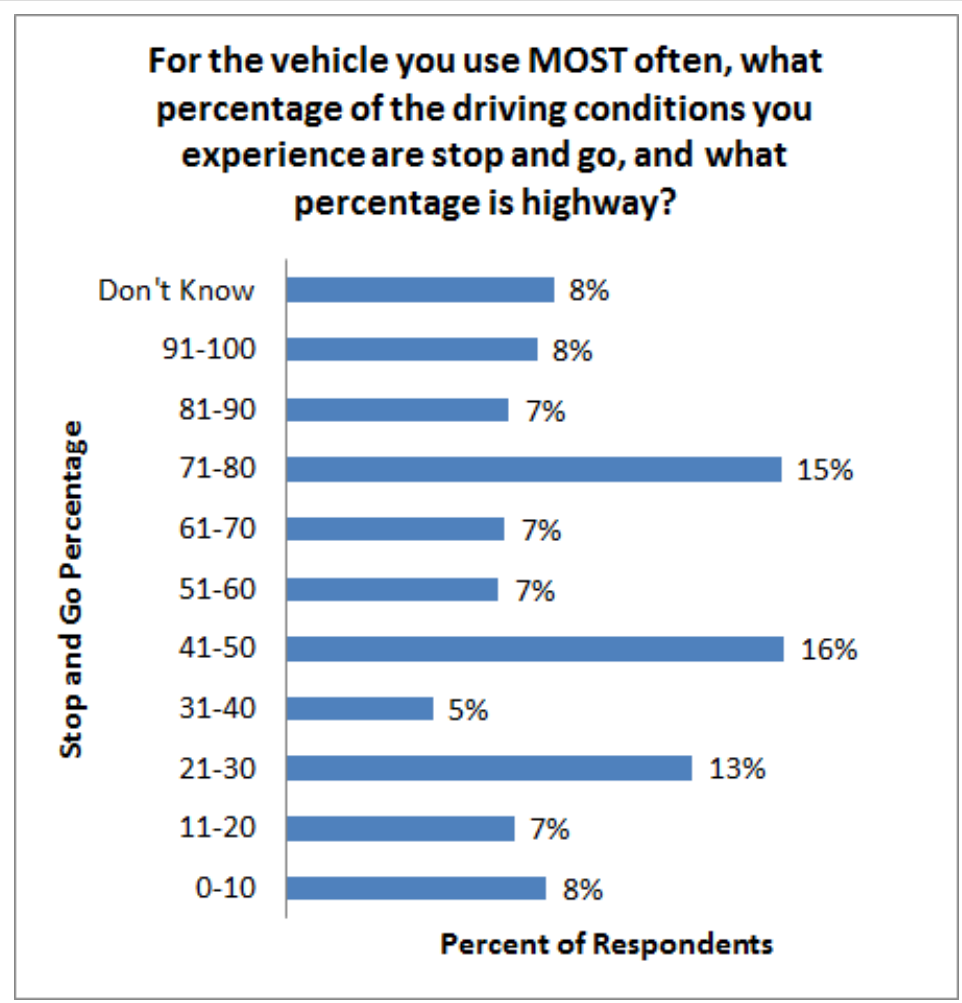

Figure 6. April 2007 question 10: Stop-and-go versus highway conditions

\section{Source:}

ORC for NREL (2007), Study No. 716159, N=939.

Note: Respondents who answered "Don't Drive" to question 8 were not asked questions 9 and 10 . 


\subsection{June 2011 Fuel Economy Ratings and Expectations}

In June 2011 respondents expected that vehicles would not reach the official fuel economy rating. A vehicle rated at $25 \mathrm{mpg}$ was on average expected to achieve just $23 \mathrm{mpg}$.

Respondents believed the vehicle would achieve $18 \mathrm{mpg}$ in a worst-case scenario and only 25 mpg under a best-case scenario.

\section{Considering fuel economy, when you see a vehicle with a rating of, for example, 25 miles per gallon...}

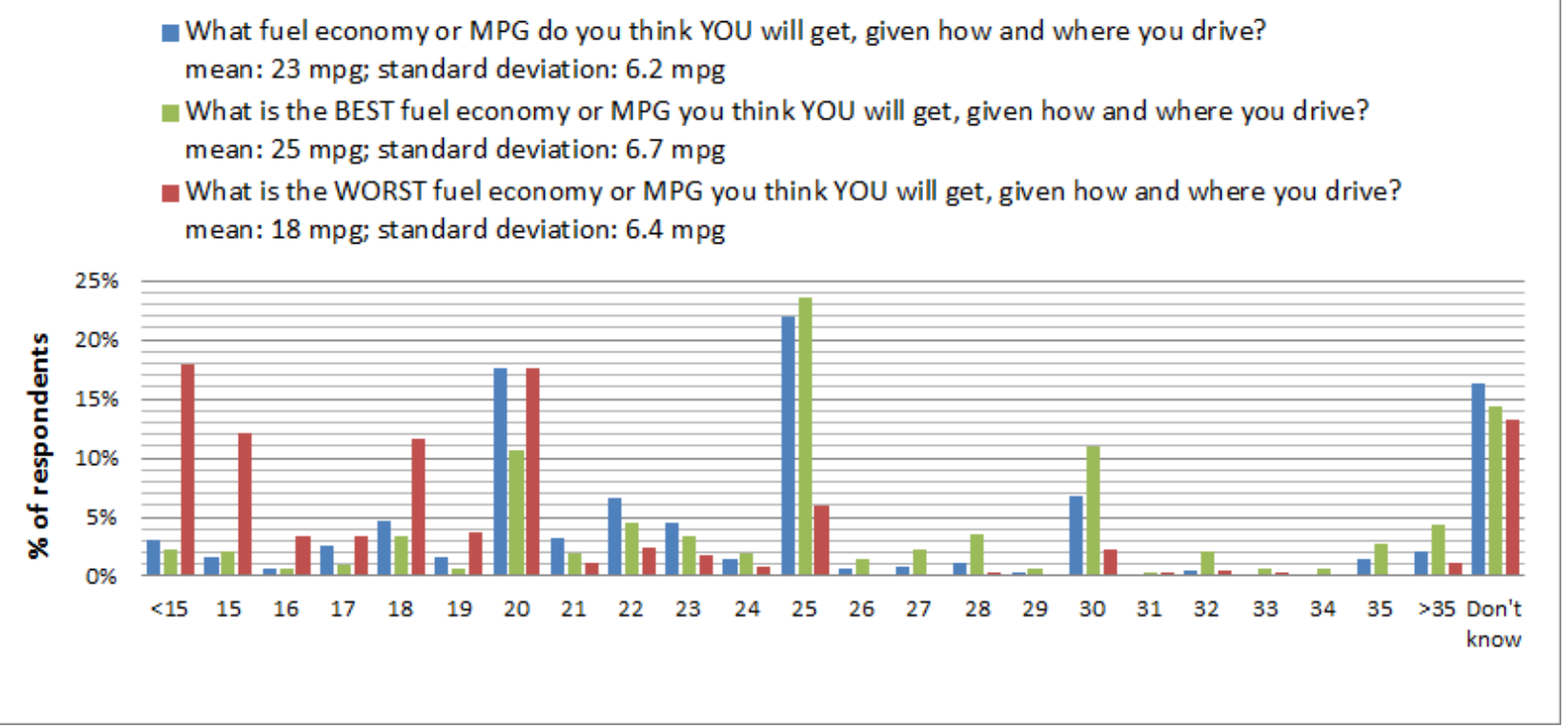

Figure 7. June 2011 question 1: Opinions on fuel economy ratings

In June 2011 a majority (55\%) of respondents stated that the difference in fuel economy ratings between two vehicles would need to be more than $6 \mathrm{mpg}$ for their decision to be affected by the ratings. Seventy-seven percent said the difference would need to be at least 5 mpg.

\begin{tabular}{|c|c|c|c|c|c|}
\hline $\begin{array}{l}\text { When comparing two vehicles you might buy, how } \\
\text { BIG DOES THE DIFFERENCE in their fuel } \\
\text { economies have to be to make it an important } \\
\text { factor in your decision? }\end{array}$ & $\begin{array}{r}1-2 \\
\mathrm{mpg}\end{array}$ & $\begin{array}{r}3-4 \\
\mathrm{mpg}\end{array}$ & $\begin{array}{r}5-6 \\
\mathrm{mpg}\end{array}$ & $\begin{array}{r}>6 \\
\mathrm{mpg}\end{array}$ & $\begin{array}{l}\text { Don't } \\
\text { Know }\end{array}$ \\
\hline Percent of Responses & $6 \%$ & $13 \%$ & $22 \%$ & $55 \%$ & $4 \%$ \\
\hline
\end{tabular}

Table 6. June 2011 Question 2: Impact of Fuel Economy When Comparing Vehicles for Purchase

\section{Source:}

ORC for NREL (2011), Study No. 720229, N=1,000. 


\subsection{June 2011 Expectation of Gasoline Price}

In June 2011, when the average U.S. gasoline price was \$3.63 per gallon, respondents on average believed the highest price they would pay for gasoline over the next 5 years was $\$ 5.40$ per gallon. Conversely respondents on average felt the lowest price they would pay for gasoline in the next 5 years would be $\$ 3.40$ per gallon. Actual gasoline prices more closely matched the respondents' low price estimate and were less volatile than the range of responses indicated.

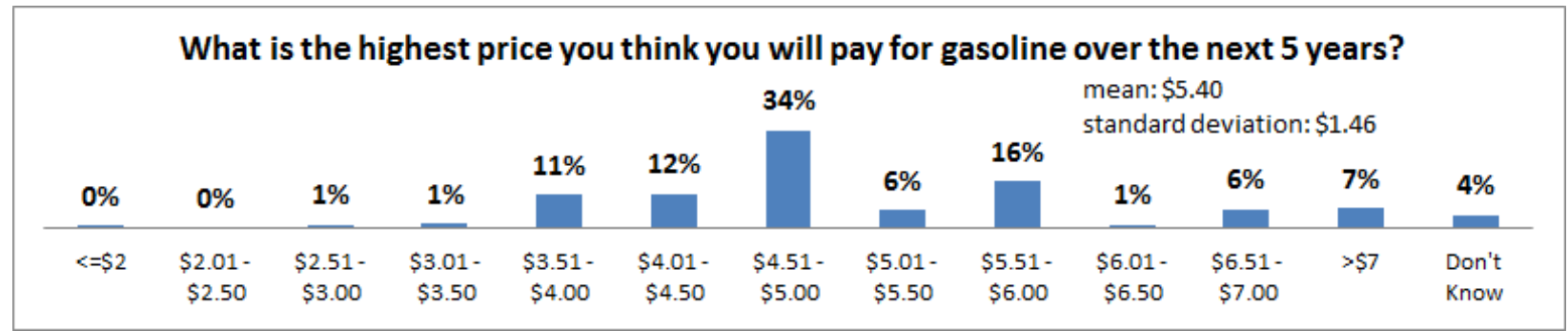

Figure 8. June 2011 question 3: Expectation of highest gasoline price

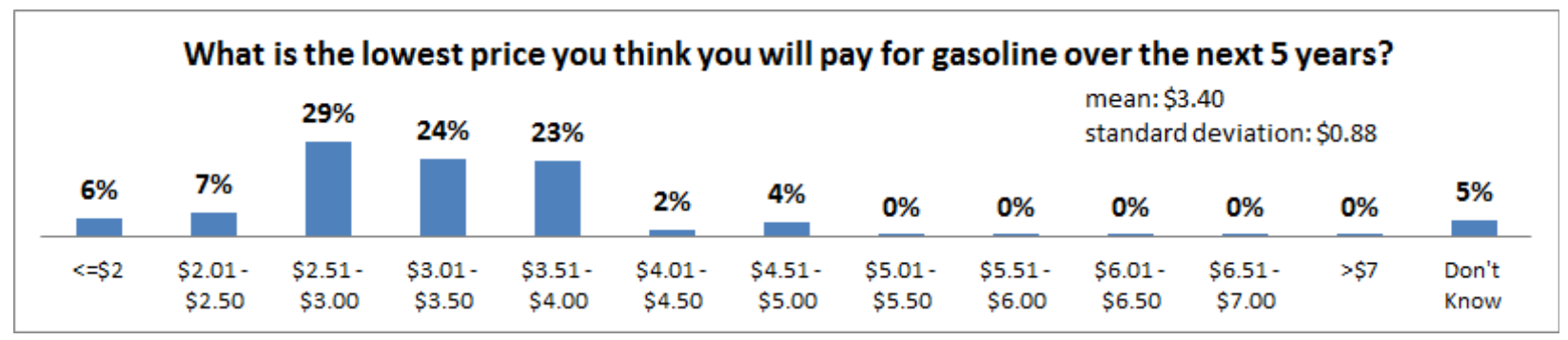

Figure 9. June 2011 question 4: Expectation of lowest gasoline price

\section{Source:}

ORC for NREL (2011), Study No. 720229, N=1,000.

\begin{tabular}{|c|c|c|c|c|c|c|c|c|c|c|c|}
\hline \multirow[b]{3}{*}{$0 \%$} & \multicolumn{10}{|c|}{ National weekly gasoline prices (212 weeks since June 2011) } & \multirow[b]{3}{*}{$0 \%$} \\
\hline & \multirow[b]{2}{*}{$6 \%$} & \multirow[b]{2}{*}{$11 \%$} & \multirow{2}{*}{$27 \%$} & \multirow[t]{2}{*}{$56 \%$} & \multirow[b]{2}{*}{$0 \%$} & \multirow[b]{2}{*}{$0 \%$} & \multicolumn{3}{|c|}{$\begin{array}{l}\text { mean: } \$ 3.43 \\
\text { standard deviation: } \$ 0.42\end{array}$} & \multirow[b]{2}{*}{$0 \%$} & \\
\hline & & & & & & & $0 \%$ & $0 \%$ & $0 \%$ & & \\
\hline$<=\$ 2$ & $\begin{array}{c}\$ 2.01- \\
\$ 2.50\end{array}$ & $\begin{array}{c}\$ 2.51- \\
\$ 3.00\end{array}$ & $\begin{array}{l}\$ 3.01- \\
\$ 3.50\end{array}$ & $\begin{array}{c}\$ 3.51- \\
\$ 4.00\end{array}$ & $\begin{array}{c}\$ 4.01- \\
\$ 4.50\end{array}$ & $\begin{array}{c}\$ 4.51- \\
\$ 5.00\end{array}$ & $\begin{array}{c}\$ 5.01- \\
\$ 5.50\end{array}$ & $\begin{array}{c}\$ 5.51- \\
\$ 6.00\end{array}$ & $\begin{array}{c}\$ 6.01- \\
\$ 6.50\end{array}$ & $\begin{array}{c}\$ 6.51- \\
\$ 7.00\end{array}$ & $>\$ 7$ \\
\hline
\end{tabular}

Figure 10. Actual national weekly gasoline price distribution since June 2011

\section{Source:}

EIA. 2015. “Gasoline and Diesel Fuel Update.” U.S. Energy Information Administration, accessed August 7, 2015: http://www.eia.gov/petroleum/gasdiesel/. 


\subsection{Attribute Importance for Vehicle Choice}

Dating back to 1980, respondents have been asked the question, "Which one of the following attributes would be MOST IMPORTANT in your choice of your next vehicle?" The trends show that the relative importance of fuel economy rose in the late 1990 s and early 2000 s. The trend has been flat to declining in recent years.

\begin{tabular}{|l|r|r|r|r|r|r|}
\hline $\begin{array}{l}\text { Date of } \\
\text { Study }\end{array}$ & $\begin{array}{r}\text { Fuel } \\
\text { Economy }\end{array}$ & $\begin{array}{r}\text { Depend- } \\
\text { ability }\end{array}$ & $\begin{array}{r}\text { Low } \\
\text { price }\end{array}$ & Quality & Safety & $\begin{array}{r}\text { Don't } \\
\text { Know }\end{array}$ \\
\hline $\mathbf{1 9 8 0}$ & $42 \%$ & $31 \%$ & $14 \%$ & $4 \%$ & $9 \%$ & \\
\hline $\mathbf{1 9 8 1}$ & $20 \%$ & $40 \%$ & $21 \%$ & $7 \%$ & $12 \%$ & \\
\hline $\mathbf{1 9 8 3}$ & $13 \%$ & $38 \%$ & $30 \%$ & $11 \%$ & $9 \%$ & \\
\hline $\mathbf{1 9 8 5}$ & $8 \%$ & $41 \%$ & $29 \%$ & $12 \%$ & $10 \%$ & \\
\hline $\mathbf{1 9 8 7}$ & $4 \%$ & $44 \%$ & $31 \%$ & $8 \%$ & $14 \%$ & \\
\hline $\mathbf{1 9 9 6}$ & $7 \%$ & $34 \%$ & $11 \%$ & $19 \%$ & $29 \%$ & \\
\hline $\mathbf{1 9 9 8}$ & $4 \%$ & $36 \%$ & $5 \%$ & $20 \%$ & $34 \%$ & $1 \%$ \\
\hline $\mathbf{2 0 0 0}$ & $10 \%$ & $32 \%$ & $11 \%$ & $21 \%$ & $24 \%$ & $2 \%$ \\
\hline $\mathbf{2 0 0 1}$ & $10 \%$ & $29 \%$ & $8 \%$ & $22 \%$ & $29 \%$ & $1 \%$ \\
\hline May 2004 & $22 \%$ & $26 \%$ & $10 \%$ & $19 \%$ & $23 \%$ & \\
\hline May 2005 & $12 \%$ & $33 \%$ & $6 \%$ & $20 \%$ & $26 \%$ & $3 \%$ \\
\hline Jun 2006 & $19 \%$ & $27 \%$ & $6 \%$ & $19 \%$ & $25 \%$ & $4 \%$ \\
\hline Aug 2007 & $21 \%$ & $30 \%$ & $7 \%$ & $17 \%$ & $24 \%$ & $3 \%$ \\
\hline Aug 2008 & $26 \%$ & $26 \%$ & $8 \%$ & $15 \%$ & $22 \%$ & $2 \%$ \\
\hline Aug 2009 & $23 \%$ & $28 \%$ & $9 \%$ & $19 \%$ & $17 \%$ & $5 \%$ \\
\hline Jun 2011 & $29 \%$ & $22 \%$ & $7 \%$ & $19 \%$ & $21 \%$ & $1 \%$ \\
\hline Nov 2012 & $27 \%$ & $23 \%$ & $13 \%$ & $15 \%$ & $14 \%$ & $7 \%$ \\
\hline Jun 2014 & $20 \%$ & $29 \%$ & $11 \%$ & $19 \%$ & $19 \%$ & $2 \%$ \\
\hline Jun 2015 & $13 \%$ & $31 \%$ & $14 \%$ & $18 \%$ & $21 \%$ & $3 \%$ \\
\hline
\end{tabular}

Table 7. Most Important Vehicle Attribute in Choice of Next Vehicle

\section{Source:}

For 1980 - 2005 (Kubik 2006); For 2006: ORC for NREL (2006), Study No. 715238, N=963.

For 2007: ORC for NREL (2007), Study No. 716328, N=1,000. For 2008: ORC for NREL (2008), Study No. 717318, N=1,000. For 2009: ORC for NREL (2009), Study No. 718339, $\mathrm{N}=1,000$. For 2011: ORC for NREL (2011), Study No. 720229, N=1,000. For 2012: ORC for NREL (2012), Study No. 721488/74348, N=1,000. For 2014: ORC for NREL (2014), Study No. 723238, N=1,014. For 2015: ORC for NREL (2015), Study No. 724268, N=1,006.

Note: The attribute most often rated as most important in each study is shaded in green while the attribute least often rated as most important is shaded in red. 


\subsection{July 2013 Vehicle Attribute Preferences}

In July 2013, "Personality or styling" was included with a list of vehicle attributes from which respondents were asked to choose the most important when purchasing vehicles. The new attribute was reported as having a relatively low value. Fuel economy dropped in relative value and showed the greatest percentage change in comparison to the most recent results (November 2012) that did not include the new attribute. The drop in the importance of fuel economy cannot be directly associated with the inclusion of the new attribute because the surveys were conducted at different times with different populations.

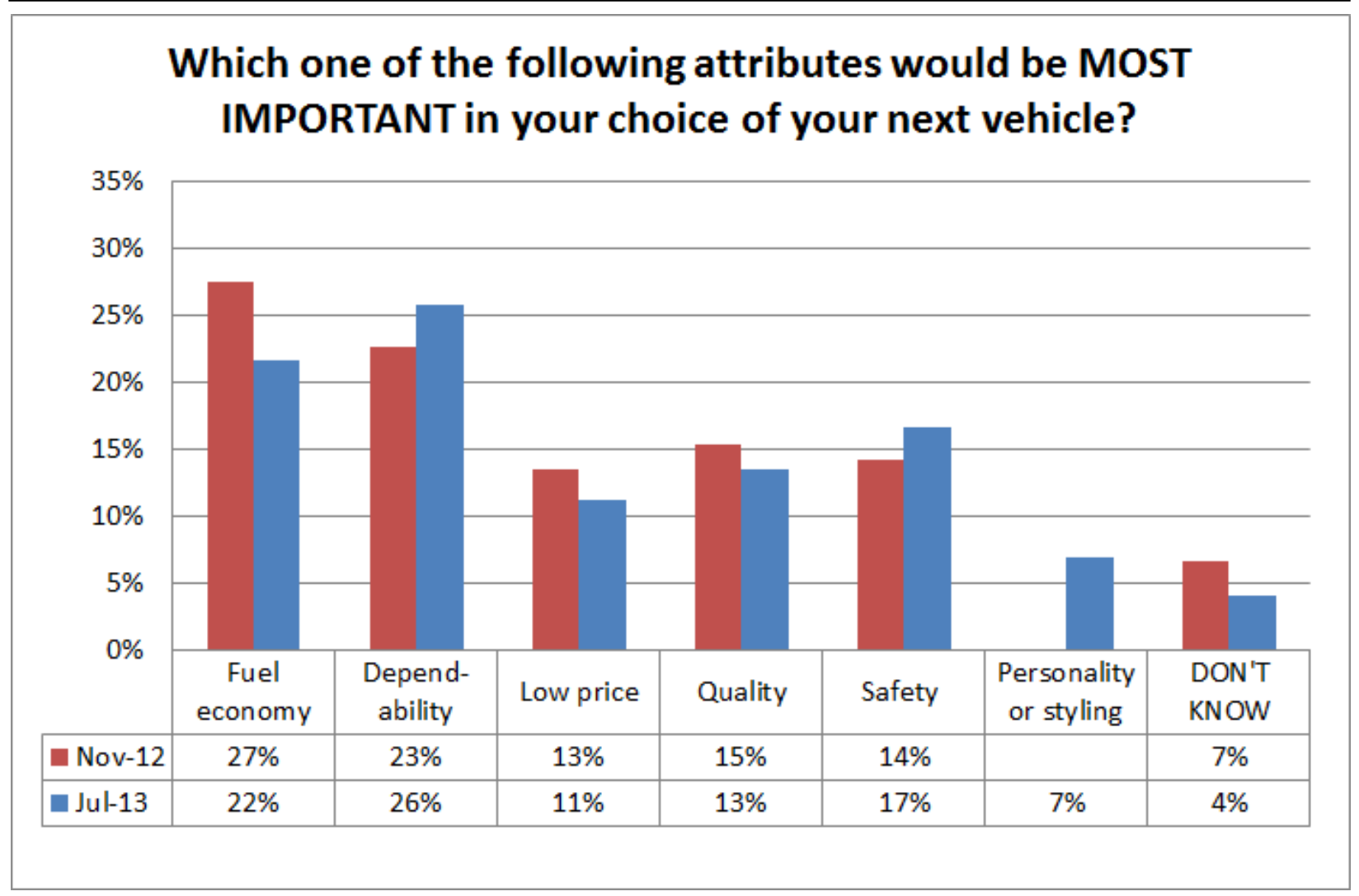

Figure 11. July 2013 question 1: Most important attribute in choosing a vehicle

\section{Sources:}

For 2012: ORC for NREL (2012), Study No. 721488, N=1,000.

For 2013: ORC for NREL (2013), Study No. 722269/74460, N=1,000. 


\subsection{July 2013 Individual Vehicle Attribute Values}

In July 2013, a broad array of attributes was shown to affect decision making during the vehicle purchase process. Respondents were asked to rate attributes on a scale from 1 to 10 . Dependability, safety, and quality received the highest ratings on average by the respondents. Fuel economy, performance, and comfort were in a second tier and rated at 8 or higher. Low price, segment, and styling were the lowest rated attributes; broader standard deviations showed more variability in these attributes' perceived importance. Although some attributes were rated higher than others, none received an average rating lower than 6 . This may mean that respondents value all of the attributes, and each could affect the final purchase decision.

\begin{tabular}{|l|r|r|}
\hline $\begin{array}{l}\text { Please rate the following attributes based on how important they are } \\
\text { for your choice of your next vehicle. Please use a scale from 1 to 10 } \\
\text { with 1 being 'very low importance' and 10 being 'very high } \\
\text { importance'. }\end{array}$ & Mean & $\begin{array}{r}\text { Standard } \\
\text { Deviation }\end{array}$ \\
\hline Dependability & 9.3 & 1.3 \\
\hline Safety & 8.9 & 1.6 \\
\hline Quality & 8.8 & 1.5 \\
\hline Fuel economy & 8.5 & 1.8 \\
\hline Performance & 8.3 & 1.9 \\
\hline Comfort & 8.0 & 1.8 \\
\hline Low price & 7.8 & 2.2 \\
\hline Segment, such as sedan, pick-up, SUV, van, etc. & 7.3 & 2.5 \\
\hline Personality or styling of the vehicle & 6.5 & 2.5 \\
\hline
\end{tabular}

Table 8. July 2013 Question 2: Rate Importance of Vehicle Attributes

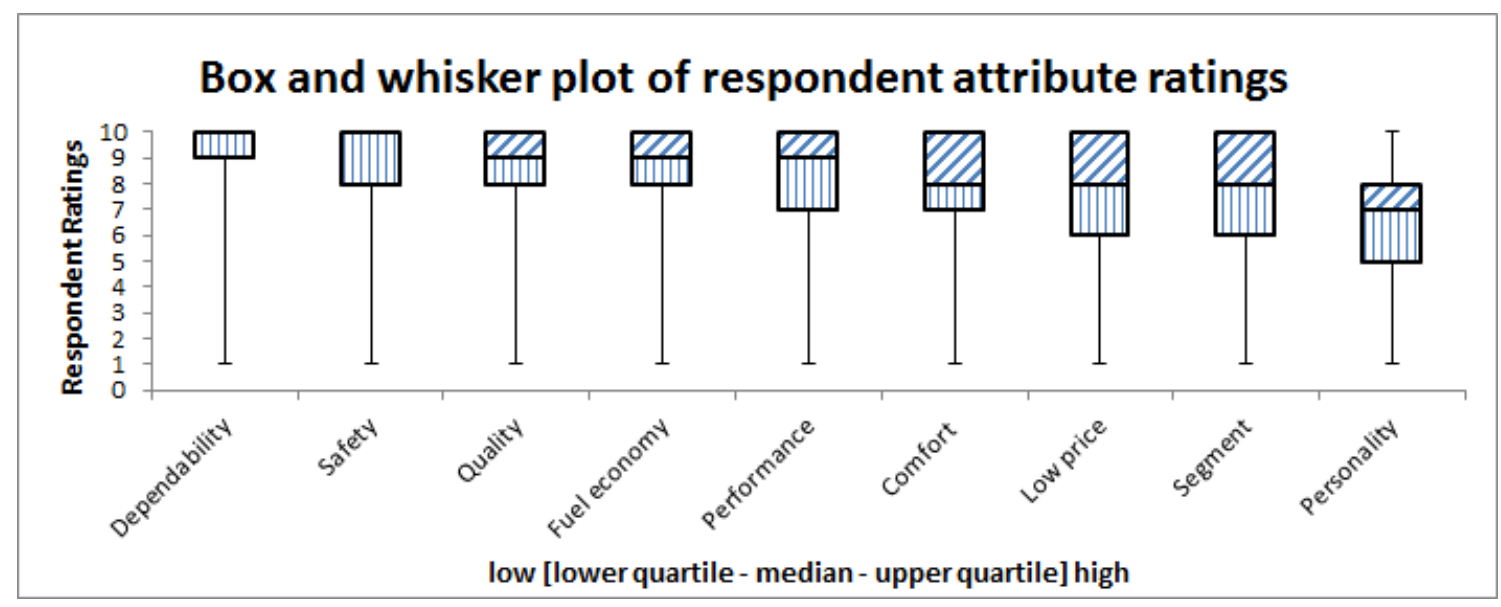

Figure 12. July 2013 question 2: Rate importance of vehicle attributes

\section{Source:}

ORC for NREL (2013), Study No. 722269/74460, N=1,000. 


\section{Future Vehicle Technology Alternatives}

\section{Contents}

2.1 Future Vehicle Technology Alternatives Overview......................................................18

2.2 December 2005 Factors that Impact Consumer Interest in Vehicle Fuel Types ..............19

2.3 The Best Replacement for Gasoline and Reasons for Electricity....................................20

2.4 Reasons Ethanol Is the Best Replacement for Gasoline.................................................21

2.5 Reasons Hydrogen Is the Best Replacement for Gasoline ................................................22

2.6 The Worst Replacement for Gasoline and Reasons for Electricity .................................2.

2.7 Reasons Ethanol Is the Worst Replacement for Gasoline.............................................24

2.8 Reasons Hydrogen Is the Worst Replacement for Gasoline ………..............................2.

2.9 August 2007/2008 Hybrid and Diesel versus Gasoline Vehicles....................................26

2.10 August 2007 Hybrid and Diesel Reasoning ...............................................................27 


\subsection{Future Vehicle Technology Alternatives Overview}

Surveys capturing sentiments toward technologies that are new to or not yet available in the marketplace can inform the efforts to develop and deploy them. Although the public may not have a strong familiarity with and understanding of the technologies, captured sentiments highlight market interest for a technology or market barriers a technology would need to overcome to be successful.

A December 2005 study inquired about respondent sentiments toward a hypothetical vehicle technology that uses a new type of fuel that costs the same as gasoline, but the fuel for which is initially not available outside the respondent's local area. The results show that a lower initial vehicle cost is enough for a significant percentage of the population to consider purchasing the vehicle. Respondents are walked through a series of conditions in the study that built upon each other. The results show a combination of factors beyond vehicle cost that drive a wider acceptance of the new technology. Consumers are interested in the vehicle fuel type being broadly available, the fuel being domestically produced, the vehicle technology being seen as cutting edge, and the technology having positive environmental impacts in comparison to conventional petroleum vehicles. Respondent acceptance tops $80 \%$ for a hypothetical vehicle with this combination of traits.

Studies were also conducted between 2000 and 2011 to track which fuel type-electricity, ethanol, and hydrogen - is viewed as the best and worst replacement for gasoline. Vehicles that can operate on high-level blends of ethanol and gasoline have been available since before 2000 (DOE 2015). Electric vehicles (EVs) most recently became available in December 2010, and hydrogen vehicles have yet to become broadly available. Electricity has been rated the highest most often; ethanol most often has been rated lowest. Regardless of the fuel type chosen, the perceived availability of the alternative fuel, positive environmental impacts, and affordability were often given as reasons for choosing the fuel as the best replacement. Further, the lack of these traits was viewed as a negative. Each fuel type had specific traits that drove negative sentiments. Respondents were concerned with performance of electricity, negative impacts on farmland of ethanol, and safety of hydrogen.

Similar studies asked respondents in 2007 and 2008 (during a petroleum price spike and subsequent financial collapse) to state a preference for purchasing a gasoline vehicle or paying an incremental cost for either a hybrid or diesel vehicle that would reduce their total fuel consumption. The majority of respondents stated they would be willing to pay the incremental cost. That majority grew between the two studies, and respondents were increasingly interested in the hybrid vehicle option. 


\subsection{December 2005 Factors that Impact Consumer Interest in Vehicle Fuel Types}

December 2005 study results show that a lower initial vehicle cost and locally available fuel are sufficient conditions for a significant percentage of the population $(38 \%$ and $48 \%$ for a vehicle that is priced $\$ 1,000$ and $\$ 4,000$, respectively, less than a conventional vehicle) to consider purchasing a new alternative fuel vehicle technology. If the fuel was available along highways and the buyer would receive a $\$ 1,000$ subsidy when purchasing the vehicle, the acceptance of the technology rose to $52 \%$ and $66 \%$ for vehicles priced $\$ 1,000$ and $\$ 4,000$, respectively, lower than conventional vehicles. Further, if the fuel was expected to be available broadly, the fuel was domestically made, and the vehicle had no tailpipe emissions while using half as much fuel per mile, acceptance of the vehicle rose to $81 \%$ and $82 \%$ for vehicles that were priced $\$ 1,000$ and $\$ 4,000$, respectively, lower than conventional vehicles.

\begin{tabular}{|c|c|c|c|}
\hline $\begin{array}{l}\text { For the next several questions, please pretend that there is } \\
\text { a new type of vehicle for sale that uses a new kind of fuel } \\
\text { that is not for sale outside your city or area. The new fuel } \\
\text { costs the same as gasoline today. } \\
\text { Version A: If this new type of vehicle costs } \$ 1,000 \text { less } \\
\text { than a conventional vehicle, would you buy it? } \\
\text { Version B: If this new type of vehicle costs } \$ 4,000 \text { less } \\
\text { than a conventional vehicle, would you buy it? }\end{array}$ & $\begin{array}{r}\text { Yes } \\
\text { (Ver. A; } \\
\text { Ver. B) }\end{array}$ & $\begin{array}{r}\text { No } \\
(\text { Ver. A; } \\
\text { Ver. B) }\end{array}$ & $\begin{array}{r}\text { Don't } \\
\text { Know/ } \\
\text { Refused } \\
\text { (Ver. A; } \\
\text { Ver. B) }\end{array}$ \\
\hline Initial Response & $38 \% ; 48 \%$ & $53 \% ; 43 \%$ & $9 \% ; 8 \%$ \\
\hline $\begin{array}{l}\text { If, in addition to being available in your city or area, the } \\
\text { fuel for this new type of vehicle were available along all } \\
\text { interstate highways and a subsidy of } \$ 1,000 \text { were provided } \\
\text { when you bought the vehicle, would you buy it? }\end{array}$ & $52 \% ; 66 \%$ & $37 \% ; 24 \%$ & $11 \% ; 10 \%$ \\
\hline $\begin{array}{l}\text { If this vehicle and fuel were the wave of the future, and the } \\
\text { fuel would be available everywhere within ten years, would } \\
\text { you buy it? }\end{array}$ & $59 \% ; 69 \%$ & $30 \% ; 22 \%$ & $11 \% ; 9 \%$ \\
\hline $\begin{array}{l}\text { If all of the previous features I just mentioned applied to } \\
\text { this new vehicle AND the fuel were } 100 \% \text { domestically } \\
\text { made, would you buy it? }\end{array}$ & $74 \% ; 79 \%$ & $17 \% ; 13 \%$ & $9 \% ; 7 \%$ \\
\hline $\begin{array}{l}\text { And, finally, if ALL of these previous features applied, AND } \\
\text { the vehicle has no tailpipe emissions AND uses half as } \\
\text { much fuel per mile as a conventional vehicle, would you } \\
\text { buy it? }\end{array}$ & $81 \% ; 82 \%$ & $13 \% ; 11 \%$ & $7 \% ; 7 \%$ \\
\hline
\end{tabular}

Table 9. December 2005: Factors That Impact Purchase of a New Vehicle Fuel Technology

\section{Source:}

ORC for NREL (2005), Study No. 714507, N=500.

Note: The study sample size was 500 respondents for both version A and version B of the question set. 


\subsection{The Best Replacement for Gasoline and Reasons for Electricity}

Respondents have periodically been asked to state whether electricity, ethanol, or hydrogen would be the best replacement for gasoline. Electricity has most often been rated as the best replacement. Ethanol has most often been lower than both electricity and hydrogen. A February 2007 study is the primary exception; ethanol was the highest-rated fuel type.

\begin{tabular}{|c|c|c|c|c|c|c|}
\hline \multirow{5}{*}{ 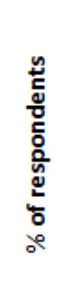 } & \multicolumn{6}{|c|}{$\begin{array}{l}\text { Consider a future date when gasoline is no longer available. Which of the } \\
\text { following do you think would be the BEST fuel for use in personal vehicles? }\end{array}$} \\
\hline & \multirow{3}{*}{$\begin{array}{l}60 \% \\
40 \% \\
20 \%\end{array}$} & \multirow{3}{*}{\multicolumn{5}{|c|}{$\longrightarrow$}} \\
\hline & & & & & & \\
\hline & & & & & & \\
\hline & $0 \%$ & 2000 & 2004 & Feb 2007 & Mar 2009 & Aug 2011 \\
\hline \multicolumn{2}{|c|}{ Electricity } & $52 \%$ & $41 \%$ & $32 \%$ & $42 \%$ & $48 \%$ \\
\hline \multicolumn{2}{|c|}{ Ethanol } & $21 \%$ & $19 \%$ & $36 \%$ & $21 \%$ & $19 \%$ \\
\hline \multicolumn{2}{|c|}{ Hydrogen } & $15 \%$ & $28 \%$ & $25 \%$ & $28 \%$ & $24 \%$ \\
\hline \multicolumn{2}{|c|}{ Don't Know } & $12 \%$ & $13 \%$ & $7 \%$ & $9 \%$ & $9 \%$ \\
\hline
\end{tabular}

Figure 13. Best replacement for gasoline

\section{Sources:}

For 2000 and 2004 (Kubik 2006); For 2007: ORC for NREL (2007), Study No. 716067 , $\mathrm{N}=1,000$. For 2009: ORC for NREL (2009), Study No. 718118, N=1,000. For 2011: ORC for NREL (2011), Study No. 720349, N=1,000.

The respondents who selected electricity stated the perceived availability of electricity was the top reason for being the best replacement for gasoline in 2007 and 2011; the percentage of respondents naming availability increased significantly in 2011.

\begin{tabular}{|l|r|r|}
\hline $\begin{array}{l}\text { Why did you say ELECTRICITY would be the BEST fuel for use in personal } \\
\text { vehicles when gasoline is no longer available? }\end{array}$ & $\begin{array}{r}\text { Feb } \\
\mathbf{2 0 0 7}\end{array}$ & $\begin{array}{r}\text { Aug } \\
\mathbf{2 0 1 1}\end{array}$ \\
\hline $\begin{array}{l}\text { Availability (abundant, common, renewable/inexhaustible, easy to } \\
\text { produce/manufacture, not dependent on foreign oil) }\end{array}$ & $27 \%$ & $46 \%$ \\
\hline $\begin{array}{l}\text { Environmental concerns (cleaner, less pollution, cleaner air, other } \\
\text { environmental mentions) }\end{array}$ & $17 \%$ & $18 \%$ \\
\hline $\begin{array}{l}\text { Existing/developing technology (electric cars already being developed, } \\
\text { technology already being used, many things powered by electricity) }\end{array}$ & $12 \%$ & \\
\hline Economical/affordable & $7 \%$ & $13 \%$ \\
\hline Most familiar with it/not familiar with others & $7 \%$ & $8 \%$ \\
\hline Methods of generating (can be solar generated, other related mentions) & $5 \%$ & $9 \%$ \\
\hline Other & $6 \%$ & $8 \%$ \\
\hline Don't know & $15 \%$ & $7 \%$ \\
\hline
\end{tabular}

\section{Sources:}

Table 10. Reasons Electricity Would Be the Best Replacement for Gasoline

For 2007: ORC for NREL (2007), Study No. 716067, N=317.

For 2011: ORC for NREL (2011), Study No. 720349, N=476. 


\subsection{Reasons Ethanol Is the Best Replacement for Gasoline}

The respondents who selected ethanol as the best replacement for gasoline most often mentioned its availability as the reason for choosing it in studies conducted in 2007 and 2011.

\begin{tabular}{|l|r|r|}
\hline $\begin{array}{l}\text { Why did you say ETHANOL would be the BEST fuel for use in personal } \\
\text { vehicles when gasoline is no longer available? }\end{array}$ & $\begin{array}{r}\text { February } \\
\mathbf{2 0 0 7}\end{array}$ & $\begin{array}{r}\text { August } \\
\mathbf{2 0 1 1}\end{array}$ \\
\hline $\begin{array}{l}\text { Readily available (common, abundant, renewable/inexhaustible, easy to } \\
\text { produce/manufacture, can generate our own fuel, other related } \\
\text { mentions) }\end{array}$ & $31 \%$ & $36 \%$ \\
\hline Methods of generating (made from corn/grain, other related mentions) & $14 \%$ & \\
\hline Economical/affordable & $10 \%$ & $14 \%$ \\
\hline Economic benefits & & $12 \%$ \\
\hline Better for/helps farmers/farming industry & $9 \%$ & \\
\hline Most familiar with it/not familiar with others & $9 \%$ & $4 \%$ \\
\hline Existing/developing technology & $8 \%$ & \\
\hline Environmental concerns (cleaner, less pollution, other related mentions) & $7 \%$ & $11 \%$ \\
\hline Others not practical/performance concerns & $6 \%$ & \\
\hline Performance & & $6 \%$ \\
\hline Electricity/Ethanol requires oil/coal for generation & & $5 \%$ \\
\hline Other & $7 \%$ & $19 \%$ \\
\hline Don't know & $12 \%$ & $7 \%$ \\
\hline
\end{tabular}

Table 11. Reasons Ethanol Would Be the Best Replacement for Gasoline

\section{Sources:}

For 2007: ORC for NREL (2007), Study No. 716067, N=358.

For 2011: ORC for NREL (2011), Study No. 720349, N=188. 


\subsection{Reasons Hydrogen Is the Best Replacement for Gasoline}

Respondents selected hydrogen as the best replacement for gasoline primarily because they saw it as better for the environment and readily available in the 2007 and 2011 studies.

\begin{tabular}{|l|r|r|}
\hline $\begin{array}{l}\text { Why did you say HYDROGEN would be the BEST fuel for use in personal } \\
\text { vehicles when gasoline is no longer available? }\end{array}$ & $\begin{array}{l}\text { February } \\
\mathbf{2 0 0 7}\end{array}$ & $\begin{array}{l}\text { August } \\
\mathbf{2 0 1 1}\end{array}$ \\
\hline Environmental concerns (cleaner, less pollution, other related mentions) & $33 \%$ & $29 \%$ \\
\hline $\begin{array}{l}\text { Availability (common, abundant, easy to produce/manufacture, } \\
\text { renewable/inexhaustible, other related mentions) }\end{array}$ & $26 \%$ & $37 \%$ \\
\hline Economical/affordable & $15 \%$ & $15 \%$ \\
\hline Others not practical/performance concerns & $13 \%$ & \\
\hline More efficient & $5 \%$ & \\
\hline Methods of generating & $5 \%$ & \\
\hline Performance & & $13 \%$ \\
\hline Prefer this fuel/Don't like other choices (unspecified) & & $7 \%$ \\
\hline Don't like that food/corn is used to produce ethanol & $7 \%$ \\
\hline Sources of generation & & $7 \%$ \\
\hline Electricity/Ethanol requires oil/coal for generation & $5 \%$ & $15 \%$ \\
\hline Other & $7 \%$ & $7 \%$ \\
\hline Don't know & & $5 \%$ \\
\hline
\end{tabular}

Table 12. Reasons Hydrogen Would Be the Best Replacement for Gasoline

\section{Sources:}

For 2007: ORC for NREL (2007), Study No. 716067, N=252.

For 2011: ORC for NREL (2011), Study No. 720349, N=242. 


\subsection{The Worst Replacement for Gasoline and Reasons for Electricity}

Interviews have asked respondents to state whether electricity, ethanol, or hydrogen would be the worst replacement for gasoline. Respondents most often stated that ethanol was the worst replacement for gasoline. This was particularly true in the 2009 and 2011 studies. Aside from the 2000 study, electricity and hydrogen have had similar percentages of the population stating they were the worst replacement for gasoline.

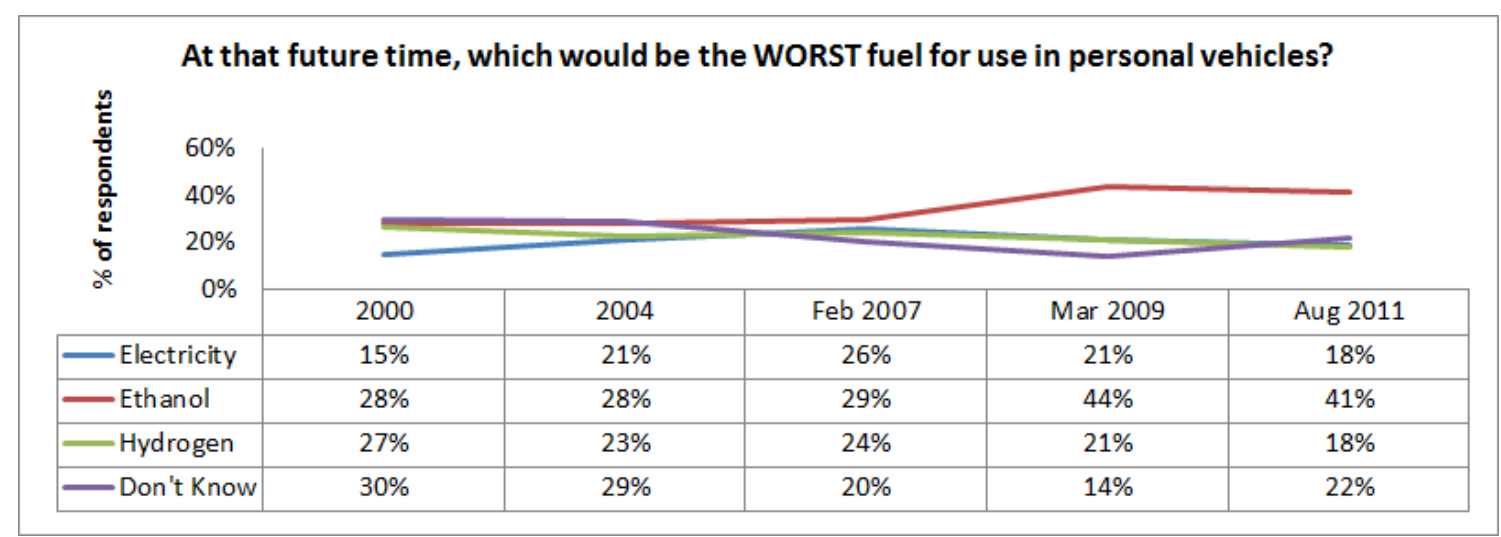

Figure 14. Worst replacement for gasoline

\section{Sources:}

For 2000 and 2004 (Kubik 2006); For 2007: ORC for NREL (2007), Study No. 716067 , $\mathrm{N}=1,000$. For 2009: ORC for NREL (2009), Study No. 718118, N=1,000. For 2011: ORC for NREL (2011), Study No. 720349, N=1,000.

The top concerns for electricity as a replacement for gasoline in the 2007 and 2011 studies were the expense of electricity and the environmental impacts of creating it. The availability and performance of electricity as a vehicle fuel were reported as significant concerns in 2011.

\begin{tabular}{|l|r|r|}
\hline $\begin{array}{l}\text { Why did you say ELECTRICITY would be the WORST fuel for use in } \\
\text { personal vehicles when gasoline is no longer available? }\end{array}$ & $\begin{array}{r}\text { February } \\
\mathbf{2 0 0 7}\end{array}$ & $\begin{array}{r}\text { August } \\
\mathbf{2 0 1 1}\end{array}$ \\
\hline Too expensive & $24 \%$ & $26 \%$ \\
\hline $\begin{array}{l}\text { Environmental concerns (must burn coal/fossil fuels, pollution, other } \\
\text { related mentions) }\end{array}$ & $20 \%$ & $22 \%$ \\
\hline Electric vehicles can't hold charge for long/can't travel long distances & $9 \%$ & \\
\hline Need to charge battery/plug it in & $7 \%$ & $4 \%$ \\
\hline Lack of availability & $4 \%$ & $19 \%$ \\
\hline Performance & & $18 \%$ \\
\hline Other & $10 \%$ & $14 \%$ \\
\hline Don't know & $10 \%$ & $4 \%$ \\
\hline
\end{tabular}

Table 13. Reasons Electricity Would Be the Worst Replacement for Gasoline

\section{Sources:}

For 2007: ORC for NREL (2007), Study No. 716067, N=256.

For 2011: ORC for NREL (2011), Study No. 720349, N=185. 


\subsection{Reasons Ethanol Is the Worst Replacement for Gasoline}

The primary concern about ethanol's use as a replacement for gasoline was related to perceived negative impacts on the environment. The percentage of respondents who named the use of farmland or food to make ethanol increased significantly between the 2007 and 2011 studies.

\begin{tabular}{|l|r|r|}
\hline $\begin{array}{l}\text { Why did you say ETHANOL would be the WORST fuel for use in } \\
\text { personal vehicles when gasoline is no longer available? }\end{array}$ & $\begin{array}{l}\text { February } \\
\mathbf{2 0 0 7}\end{array}$ & $\begin{array}{l}\text { August } \\
\mathbf{2 0 1 1}\end{array}$ \\
\hline $\begin{array}{l}\text { Environmental concerns (pollution, creates environmental problems, } \\
\text { other related mentions) }\end{array}$ & $23 \%$ & $24 \%$ \\
\hline Uses food/farmland to produce fuel & $10 \%$ & $21 \%$ \\
\hline Too expensive & $10 \%$ & $15 \%$ \\
\hline $\begin{array}{l}\text { Safety concerns (flammable/combustible, explosive, contains } \\
\text { chemicals, other related mentions) }\end{array}$ & $10 \%$ & $3 \%$ \\
\hline Not familiar with it as a fuel for vehicles & $6 \%$ & \\
\hline Difficult to produce & $5 \%$ & \\
\hline Lack of availability & $4 \%$ & $16 \%$ \\
\hline Causes engine trouble & $2 \%$ & $7 \%$ \\
\hline Performance & & $7 \%$ \\
\hline Don't know much about it & & $6 \%$ \\
\hline Other & $6 \%$ & $6 \%$ \\
\hline Don't know & $20 \%$ & $8 \%$ \\
\hline
\end{tabular}

Table 14. Reasons Ethanol Would Be the Worst Replacement for Gasoline

\section{Sources:}

For 2007: ORC for NREL (2007), Study No. 716067, N=294.

For 2011: ORC for NREL (2011), Study No. 720349, N=412. 


\subsection{Reasons Hydrogen Is the Worst Replacement for Gasoline}

Respondents most often listed safety concerns as the top reason for naming hydrogen as the worst replacement for gasoline in the 2007 and 2011 studies.

\begin{tabular}{|l|r|r|}
\hline $\begin{array}{l}\text { Why did you say HYDROGEN would be the WORST fuel for use in } \\
\text { personal vehicles when gasoline is no longer available? }\end{array}$ & $\begin{array}{r}\text { February } \\
\mathbf{2 0 0 7}\end{array}$ & $\begin{array}{r}\text { August } \\
\mathbf{2 0 1 1}\end{array}$ \\
\hline $\begin{array}{l}\text { Safety concerns (explosive, flammable/combustible, unstable, think of } \\
\text { bombs, other related mentions) }\end{array}$ & $35 \%$ & $39 \%$ \\
\hline Not familiar with it as a fuel for vehicles & $9 \%$ & \\
\hline Too expensive & $7 \%$ & $4 \%$ \\
\hline Lack of availability & $4 \%$ & $15 \%$ \\
\hline Don't know much about it & & $12 \%$ \\
\hline Environmental concerns & & $5 \%$ \\
\hline Other & $10 \%$ & $6 \%$ \\
\hline Don't know & $29 \%$ & $19 \%$ \\
\hline
\end{tabular}

Table 15. Reasons Hydrogen Would Be the Worst Replacement for Gasoline

\section{Sources:}

For 2007: ORC for NREL (2007), Study No. 716067, N=245.

For 2011: ORC for NREL (2011), Study No. 720349, N=183. 


\subsection{August 2007/2008 Hybrid and Diesel versus Gasoline Vehicles}

The majority of respondents in the 2007 and 2008 studies stated they would be willing to pay a $\$ 3,000$ incremental cost for a more fuel-efficient diesel vehicle or HEV. The majority increased from $64 \%$ in 2007 to $74 \%$ in 2008 . The number of respondents who stated they would purchase the hypothetical hybrid vehicle increased by $8 \%$ from 2007 to 2008 .

\begin{tabular}{|l|r|r|}
\hline $\begin{array}{l}\text { Assume that a HYBRID vehicle and a clean DIESEL vehicle both } \\
\text { would cost \$3,000 more than a comparable GASOLINE vehicle and } \\
\text { both would reduce your annual fuel use by 30\%. Which of the } \\
\text { following would you choose for you NEXT NEW vehicle purchase? }\end{array}$ & $\begin{array}{r}\text { August } \\
\mathbf{2 0 0 7}\end{array}$ & $\begin{array}{r}\text { August } \\
\mathbf{2 0 0 8}\end{array}$ \\
\hline Gasoline & $33 \%$ & $22 \%$ \\
\hline Diesel & $12 \%$ & $14 \%$ \\
\hline Hybrid & $52 \%$ & $60 \%$ \\
\hline Don't know & $4 \%$ & $4 \%$ \\
\hline
\end{tabular}

Table 16. Comparison of Hybrid and Diesel Vehicles with Conventional Gasoline Vehicles

\section{Sources:}

For 2007: ORC for NREL (2007), Study No. 716328, N=1,000.

For 2008: ORC for NREL (2008), Study No. 717318, N=1,000.

In 2007 the top reason given for selecting a conventional gasoline vehicle over a more efficient diesel or hybrid vehicle was the respondents' familiarity with the technology.

\begin{tabular}{|l|r|}
\hline Why did you make this choice? (Gasoline) & $\begin{array}{r}\text { Percent of } \\
\text { responses }\end{array}$ \\
\hline Familiarity & $25 \%$ \\
\hline Positive gasoline mentions (readily available, just prefer gasoline, other) & $20 \%$ \\
\hline Negative hybrid mentions (not proven, too small, other) & $19 \%$ \\
\hline Cost of vehicle & $15 \%$ \\
\hline Low cost of gasoline & $13 \%$ \\
\hline Negative diesel mentions (bad smell, noisy, difficult to start, other) & $10 \%$ \\
\hline Other & $5 \%$ \\
\hline Don't know & $7 \%$ \\
\hline
\end{tabular}

Table 17. Reasons for Selecting a Conventional Gasoline Vehicle over a Hybrid or Diesel Vehicle

\section{Sources:}

ORC for NREL (2007), Study No. 716328, N=328. 


\subsection{August 2007 Hybrid and Diesel Reasoning}

In 2007 respondents who chose a more fuel efficient diesel vehicle over an HEV or a conventional gasoline vehicle did so primarily due to generalized positive sentiments toward diesel fuel. The respondents who selected an HEV did so primarily because they felt the technology was better for the environment.

\begin{tabular}{|l|r|}
\hline Why did you make this choice? (Diesel) & $\begin{array}{r}\text { Percent of } \\
\text { responses }\end{array}$ \\
\hline Positive diesel mentions (more power, lasts longer, biodiesel, other) & $47 \%$ \\
\hline Cost of fuel & $15 \%$ \\
\hline Energy efficient & $15 \%$ \\
\hline Negative hybrid mentions (not proven, too small, other) & $15 \%$ \\
\hline Better for the environment & $14 \%$ \\
\hline Familiarity & $10 \%$ \\
\hline Other & $1 \%$ \\
\hline Don't know & $2 \%$ \\
\hline
\end{tabular}

Table 18. Reasons for Selecting a Diesel Vehicle over a Hybrid or Conventional Gasoline Vehicle

Sources:

ORC for NREL (2007), Study No. 716328, N=118.

\begin{tabular}{|l|r|}
\hline Why did you make this choice? (Hybrid) & $\begin{array}{r}\text { Percent of } \\
\text { responses }\end{array}$ \\
\hline Better for the environment & $49 \%$ \\
\hline Energy efficient & $29 \%$ \\
\hline Cost of gasoline too high & $26 \%$ \\
\hline Positive hybrid mentions & $19 \%$ \\
\hline Cost of vehicle (better in long run, other) & $6 \%$ \\
\hline Negative diesel mentions (bad smell, noisy, difficult to start, other) & $5 \%$ \\
\hline Other & $1 \%$ \\
\hline Don't know & $2 \%$ \\
\hline
\end{tabular}

Table 19. Reasons for Selecting a Hybrid Vehicle over a Conventional Gasoline or Diesel Vehicle

\section{Sources:}

ORC for NREL (2007), Study No. 716328, N=515. 


\section{Ethanol Perceptions}

\section{Contents}

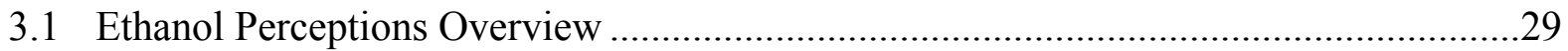

3.2 September 2006 E85 Awareness and Positive E85 Opinions .....................................30

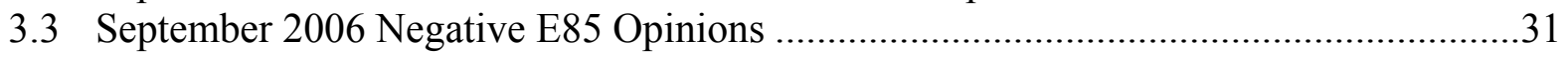

3.4 September 2006 Perceived E85 Availability and FFV Awareness ...............................32

3.5 September 2006 Amount Willing To Pay for E85 ..............................................33

3.6 September 2006 Distance Willing To Drive for E85 ...............................................34

3.7 September 2006 Willingness To Pay More for E85 versus Gasoline ............................35 


\subsection{Ethanol Perceptions Overview}

Ethanol is a renewable fuel made from corn and other plant materials and was the focus of a September 2006 study that investigated awareness of and sentiments toward the alternative fuel E85, which is a high-level gasoline-ethanol blend containing 51\%-83\% ethanol. Focus on ethanol was high in 2006, and President George W. Bush mentioned it in the State of the Union Address (Washington Post 2006). Unlike some other alternative fuels and vehicles at the time, ethanol was becoming available in the marketplace. In 2006, 762 stations were selling E85 across the country (DOE 2014) and 22 vehicle makes and models (DOE 2015) were available at the time as flex-fuel vehicles (FFVs) that could operate on E85. However, E85 stations were located primarily in the midwestern states, and even though the technology was somewhat available, it was not widespread or equally available across the country.

The study showed that general awareness and understanding of the technology was low. Only $31 \%$ of respondents had an opinion of the fuel type. Eighty-one percent of respondents either did not know if E85 was available near them or knew that it was not available. Seventy-eight percent of respondents could not name a specific make and model that could operate on E85.

Once respondents were given some additional information about E85, they reported a willingness to go out of their way to find the fuel and to pay more for the fuel. Sixty-six percent reported a willingness to go 2 miles or more out of their way to use E85. Fifty-seven percent were willing to pay an increase in fuel costs of $10 \%$ or higher in order to use the fuel.

A part of the study informed the respondents that using E85 regularly would require them to purchase fuel more often because E85 has a lower energy content than gasoline. Respondents were told to consider the hypothetical situation in which gasoline costs $\$ 3$ per gallon and they would need to fill up 33\% more often if they operated their vehicle on E85. At $\$ 3$ per gallon gasoline, respondents would need to pay $\$ 2.25$ per gallon of E85 to pay the same amount in fuel costs compared to gasoline over time. The price of gasoline at the time of the study was near $\$ 2.50$ per gallon, but the price had fallen after being close to $\$ 3$ in the preceding months. The $\$ 3$ price mentioned in the question should have reflected recent customer purchase prices. Under this question framing, $28 \%$ of respondents reported they would be willing to pay more than the $\$ 2.25$ break-even price, meaning they would pay more in fuel costs over time.

Respondents were then asked more directly if they would be willing to pay more or less for E85 compared to their current gasoline fuel costs. Under the more direct framing $68 \%$ of respondents would be willing to pay more in fuel costs to use E85 regularly in comparison to gasoline.

In summary, when the respondents were initially asked to consider a specific fuel price they would be willing to pay, only $28 \%$ voiced a willingness to pay more for E85. However, when respondents were asked how much more they might be willing to pay to fuel with E85, 68\% stated they were willing to pay more to use E85. The difference in responses may show that respondents do not have fixed perceptions about what they would be willing to pay to use E85 in comparison to gasoline. 


\subsection{September 2006 E85 Awareness and Positive E85 Opinions}

In September 2006 respondents were primarily unaware of E85. Of the 31\% who did have an opinion of E85, more (22\%) believed E85 (a blend of up to 85\% ethanol and 15\% gasoline), was as good as or better than gasoline than those that believed it was not as good as gasoline (9\%). Respondents who stated E85 was better than gasoline did so because they believed the fuel was better for the environment and would reduce the nation's dependence on foreign oil.

\begin{tabular}{|l|r|}
\hline What is your opinion of E85? Would you say... & Percent of Responses \\
\hline It's better than gasoline & $7 \%$ \\
\hline It's just as good as gasoline & $15 \%$ \\
\hline It's not as good as gasoline & $9 \%$ \\
\hline Or, you do not know anything about it & $69 \%$ \\
\hline
\end{tabular}

Table 20. September 2006 Question 1: E85 Comparison to Gasoline

Source:

ORC for NREL (2006), Study No. 715369, N=1,000.

\begin{tabular}{|l|r|}
\hline Why do you say E85 is better than gasoline? & \# of Mentions \\
\hline Pollutes less/Burns cleaner/Better for environment & 39 \\
\hline Reduces dependence on foreign oil & 13 \\
\hline Better mileage/More fuel-efficient & 8 \\
\hline Costs less/Cheaper & 7 \\
\hline Renewable/Won't run out & 5 \\
\hline Contains ethanol & 5 \\
\hline More natural & 4 \\
\hline Can be produced in this country & 4 \\
\hline Supports/Benefits farmers & 4 \\
\hline Conserves resources/Uses less gasoline & 3 \\
\hline Other & 7 \\
\hline Don't know & 3 \\
\hline
\end{tabular}

Table 21. September 2006 Question 2: Reasons for Positive E85 Sentiments

\section{Source:}

ORC for NREL (2006), Study No. 715369, N=71. 


\subsection{September 2006 Negative E85 Opinions}

In September 2006 9\% of respondents stated E85 was not as good as gasoline. These respondents believed the fuel reduces vehicle performance compared to gasoline. The most often stated performance issue when operating on E85 was a reduction in vehicle fuel mileage compared to operating on gasoline.

\begin{tabular}{|l|r|}
\hline Why do you say E85 is not as good as gasoline? & \# of Mentions \\
\hline Lower mileage/Less fuel-efficient & 40 \\
\hline Has less power than gasoline & 13 \\
\hline Lower octane rating/Burns faster & 10 \\
\hline Damages/Not good for engine & 10 \\
\hline Costs more/Expensive & 8 \\
\hline Not readily available & 7 \\
\hline Takes too much energy/Costs too much to produce & 7 \\
\hline Not made for current engines & 6 \\
\hline Dissolves rubber gaskets/fuel lines & 5 \\
\hline Costs more because less fuel-efficient & 4 \\
\hline Not as good as gasoline/Prefer gasoline (unspecified) & 3 \\
\hline Hasn't been proven/Needs more testing & 2 \\
\hline Other & 12 \\
\hline Don't know & 10 \\
\hline
\end{tabular}

Table 22. September 2006 Question 3: Reasons for Negative E85 Sentiments

\section{Source:}

ORC for NREL (2006), Study No. 715369, N=87. 


\subsection{September 2006 Perceived E85 Availability and FFV Awareness}

In September 2006 after initial questions investigated respondent sentiments toward E85 compared to gasoline, respondents were told "E85 is a mix of $85 \%$ ethanol and $15 \%$ gasoline by volume." A large majority (81\%) then stated that E85 was not available or that they did not know if E85 was available where they drive. Respondents were then told "Flexible fuel vehicles can run on any mixture of gasoline and E85. Only flexible fuel vehicles can use E85. There are about 6 million flexible fuel vehicles on the road in the U.S." Twenty-two percent of respondents could then name a specific FFV make and model.

\begin{tabular}{|l|r|}
\hline Is E85 available where you drive? Would you say... & $\begin{array}{r}\text { Percent of } \\
\text { Responses }\end{array}$ \\
\hline Yes, it's easy to find & $6 \%$ \\
\hline Yes, but few stations sell it & $13 \%$ \\
\hline No, it is not sold where I drive & $65 \%$ \\
\hline Don't know & $16 \%$ \\
\hline
\end{tabular}

Table 23. September 2006 Question 4: Perception of E85 Availability

\section{Source:}

ORC for NREL (2006), Study No. 715369, N=1,000.

\begin{tabular}{|l|r|}
\hline $\begin{array}{l}\text { Can you name any of the vehicles which are flexible fuel vehicles? } \\
\text { Please name as many as you can. }\end{array}$ & $\begin{array}{r}\text { Percent of } \\
\text { Responses }\end{array}$ \\
\hline Chrysler Town and Country & $0 \%$ \\
\hline Dodge Caravan & $2 \%$ \\
\hline Ford Explorer & $4 \%$ \\
\hline Ford Taurus & $3 \%$ \\
\hline GM Silverado & $2 \%$ \\
\hline GM Suburban & $1 \%$ \\
\hline Other & $16 \%$ \\
\hline Don't know/ None & $78 \%$ \\
\hline
\end{tabular}

Table 24. September 2006 Question 5: E85 Vehicle Awareness

\section{Source:}

ORC for NREL (2006), Study No. 715369, N=1,000.

Note: Respondents were allowed to mention multiple vehicle makes and models; responses were grouped accordingly. 


\subsection{September 2006 Amount Willing To Pay for E85}

In September 2006 respondents were first given the information that, "As you may know, the following are some of the vehicles that are flexible fuel vehicles: Ford Taurus and Explorer, GM Silverado and Suburban, Dodge Caravan, and Chrysler Town and Country. E85 has the advantage of being a domestic fuel with lower greenhouse gas emissions than gasoline.

Because there's less energy in a gallon of E85 than gasoline, your vehicle will go only about $75 \%$ as far on a tankful, so you will have to refuel $33 \%$ more often." When respondents were asked how much they would be willing to pay for E85 if gasoline were $\$ 3$ per gallon, $47 \%$ responded with the break-even price of $\$ 2.25$ or less. Twenty-eight percent responded with a price higher than $\$ 2.25$. Six percent responded they would never purchase the fuel and the remaining 19\% did not know what price they might consider.

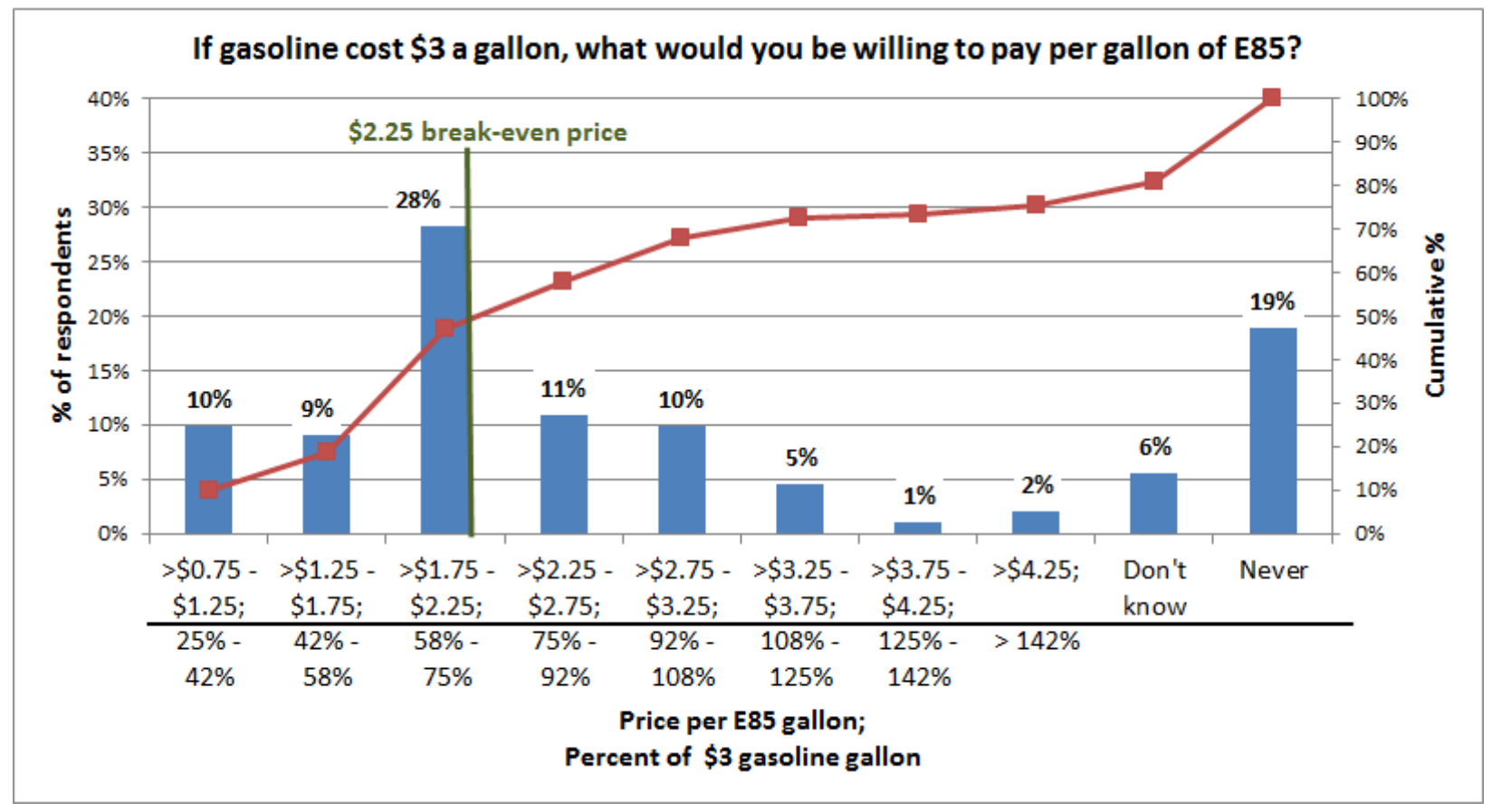

Figure 15. September 2006 question 6: Amount willing to pay for E85

\section{Source:}

ORC for NREL (2006), Study No. 715369, N=1,000. 


\subsection{September 2006 Distance Willing To Drive for E85}

In September 2006 respondents were asked, "If relatively few gas stations sell E85, how much farther would you be willing to drive one way to find a gas station that offers E85, assuming the price you would be willing to pay in the previous question? Would you say...." The survey results showed $66 \%$ of respondents would be willing to travel 2 miles or more. Forty-three percent would be willing to travel 4 miles or more.

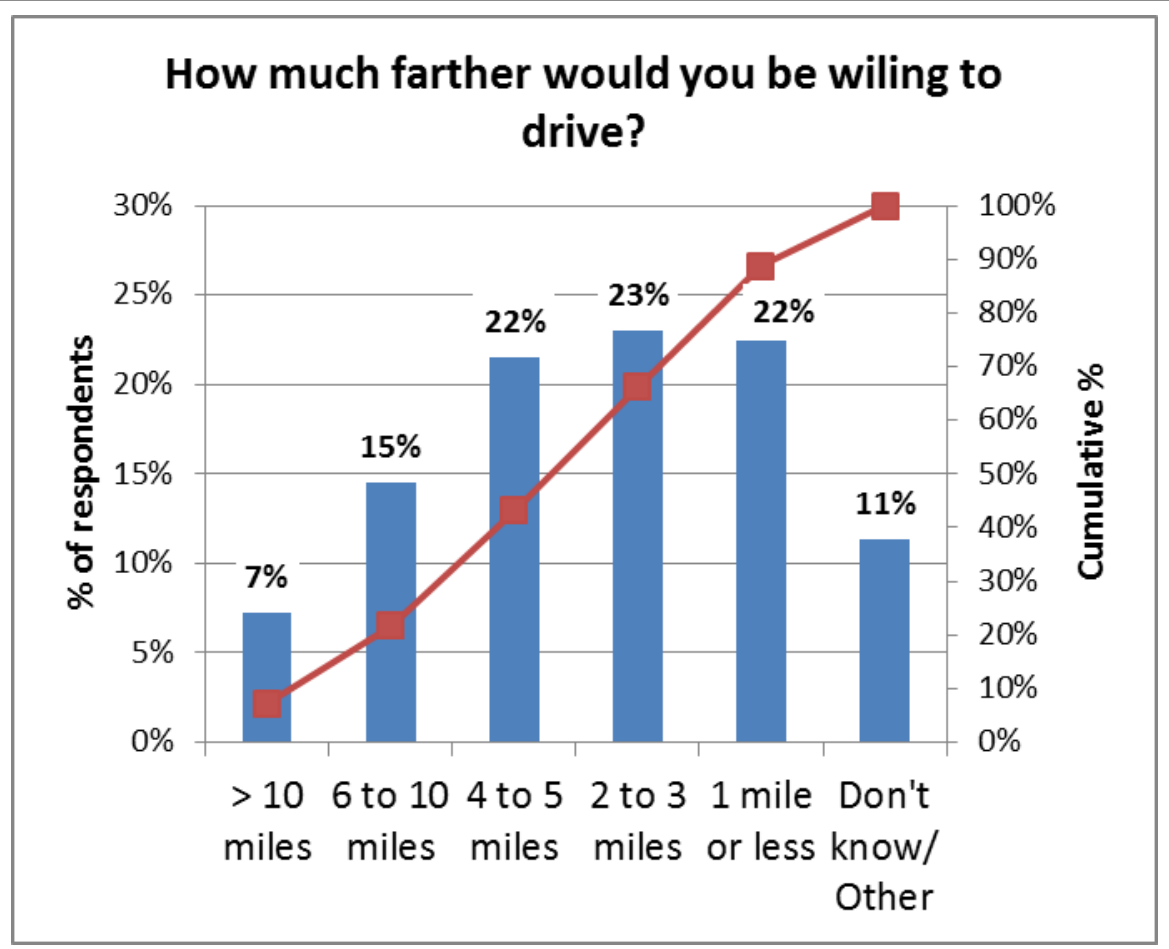

Figure 16. September 2006 question 7: Distance willing to drive for E85

\section{Source:}

ORC for NREL (2006), Study No. 715369, N=1,000. 


\subsection{September 2006 Willingness To Pay More for E85 Versus Gasoline}

In September 2006, when respondents were asked directly if they would be willing to pay more for E85, 57\% of respondents reported they would be willing to pay an increase in fuel costs of $10 \%$ or higher to use E85 regularly. Eighty-one percent would be willing to use E85 if total fuel costs would be the same as they currently pay for gasoline. Eight percent of respondents stated they would not use E85 even if the costs were lower than gasoline.

\begin{tabular}{|l|r|r|r|}
\hline $\begin{array}{l}\text { If your vehicle could use either gasoline or E85, and E85 } \\
\text { were widely available, would you buy E85 consistently if } \\
\text { your fuel expenditures for E85 compared with your current } \\
\text { gasoline expenditures were ... }\end{array}$ & Yes & No & $\begin{array}{r}\text { Don't } \\
\text { Know }\end{array}$ \\
\hline $\mathbf{1 0 \%}$ or more higher & $57 \%$ & $33 \%$ & $10 \%$ \\
\hline $\mathbf{1 \%}$ to 9\% higher & $68 \%$ & $24 \%$ & $9 \%$ \\
\hline The same & $81 \%$ & $13 \%$ & $6 \%$ \\
\hline $\mathbf{1 \%}$ to $9 \%$ lower & $87 \%$ & $8 \%$ & $5 \%$ \\
\hline $\mathbf{1 0} \%$ or more lower & $90 \%$ & $6 \%$ & $5 \%$ \\
\hline
\end{tabular}

Table 25. September 2006 Question 8: Willingness to Pay More for E85 versus Gasoline

\section{Source:}

ORC for NREL (2006), Study No. 715369, N=1,000. 


\section{Plug-in Electric Vehicle Sentiments}

\section{Contents}

4.1 Plug-in Electric Vehicle Sentiments Overview .............................................................37

4.2 June 2006 Type of Vehicle for Next Planned Purchase and Willingness To Purchase a

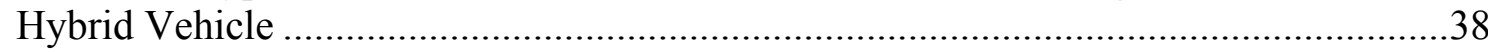

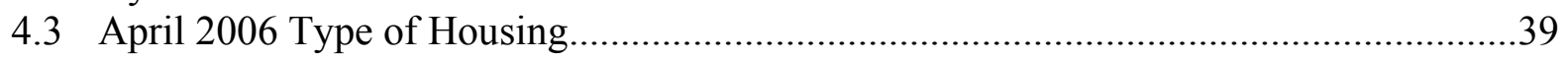

4.4 April 2006 Parking Location and Electricity Availability ……………............................40

4.5 April 2006 Awareness of PHEVs and Household Fit .....................................................4

4.6 July 2013 Plug-in Electric Vehicle Awareness and Exposure .......................................42

4.7 July 2013 PEVs versus Conventional Gasoline Vehicles ...............................................43

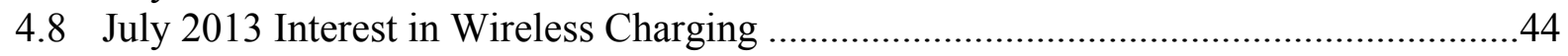




\subsection{Plug-in Electric Vehicle Sentiments Overview}

PEVs are broadly defined as vehicles that can be plugged in, are powered by an electric motor, and use energy stored in an onboard battery. The definition includes pure EVs that are powered by the electric motor only as well as plug-in hybrid electric vehicles (PHEVs) that can also be powered by an internal combustion engine fueled by petroleum fuel. PEVs most recently have been available to consumers in the United States since December 2010. These vehicles are different from HEVs, which are powered by an internal combustion engine and an electric motor that uses energy stored in a battery. The battery in a hybrid electric vehicle (HEV) cannot be plugged in; it is charged through regenerative braking and by the internal combustion engine.

Studies in April and June 2006 were completed before PEVs were introduced. The April 2006 study investigated how consumers park their vehicles and whether they could plug a vehicle in at home. Fifty-seven percent of respondents believed they would be able to plug in a hypothetical PHEV where they park their vehicles at home. A similar percentage of respondents (56\%) believed a PHEV could be a good fit with their homes. A large majority of respondents (77\%) stated that they had already heard of PHEVs even though none were currently available in the marketplace.

The June 2006 study investigated consumer interest in vehicle segments and their potential interest in purchasing a PHEV or an HEV. The study found that only a minority $(24 \%)$ of respondents were considering a small sedan, the segment in which the PEV technologies would first become available. For the PEV technologies to be more broadly accepted they would likely need to become available in more diverse vehicle segments. The majority of respondents $(68 \%)$ did state a willingness to consider an HEV or a PHEV that included an incremental cost. A hypothetical HEV with a $\$ 2,000$ incremental cost was preferred over a hypothetical PHEV with a $\$ 4,000$ incremental cost.

A July 2013 study investigated sentiments after the technology had been available for more than 2 years. Forty-seven percent of respondents believed PEVs were just as good as or better than gasoline vehicles. Nearly half the respondents could name a PEV. A small but not insignificant minority $(14 \%)$ claimed to have driven or ridden in a PEV. Respondents who reported having been in a PEV were more likely to view PEVs positively. Some respondents might have been confused between HEVs and PEVs, but nonetheless a percentage of respondents stated they had been exposed to PEVs. The study also found that technology that would allow for wireless charging of vehicles would increase the interest in PEVs for $50 \%$ of respondents. 


\subsection{June 2006 Type of Vehicle for Next Planned Purchase and Willingness To Purchase a Hybrid Vehicle}

In June 2006 consumers expressed a desire to acquire larger, typically less fuel-efficient vehicles. A minority of respondents $(24 \%)$ in 2006 were planning to purchase small cars. A majority of respondents $(68 \%)$ were willing to consider an HEV or a PHEV option and incur an incremental cost (\$2,000 for an HEV and \$4,000 for a PHEV) if those options could attain a significant mpg improvement (40\%) over the conventional version of the vehicle.

\begin{tabular}{|l|r|}
\hline $\begin{array}{l}\text { For your next NEW household vehicle, which ONE of the following are you } \\
\text { planning to purchase? }\end{array}$ & $\begin{array}{r}\text { Percent of } \\
\text { Responses }\end{array}$ \\
\hline A small car, smaller than the Chevy Malibu, Toyota Camry, or Dodge Stratus & $24 \%$ \\
\hline An SUV or sport utility vehicle & $22 \%$ \\
\hline $\begin{array}{l}\text { A large car, same size or larger than the Chevy Malibu, Toyota Camry, or } \\
\text { Dodge Stratus }\end{array}$ & $15 \%$ \\
\hline A pickup truck or standard van & $12 \%$ \\
\hline A minivan & $9 \%$ \\
\hline Don't drive & $4 \%$ \\
\hline Don't know/None of these/Will not purchase vehicle & $15 \%$ \\
\hline
\end{tabular}

Table 26. June 2006 Question 1: Type of Vehicle for Next Planned Purchase

Source:

ORC for NREL (2006), Study No. 715238, N=1,000.

\begin{tabular}{|l|r|}
\hline $\begin{array}{l}\text { Assuming that gasoline prices remain in the range of } \mathbf{\$ 2 . 5 0} \text { to } \mathbf{\$ 3} \text { per gallon, } \\
\text { for your next new vehicle purchase, would you ... }\end{array}$ & $\begin{array}{r}\text { Percent of } \\
\text { Responses }\end{array}$ \\
\hline $\begin{array}{l}\text { Pay an additional } \mathbf{\$ 2 , 0 0 0} \text { to buy a hybrid version of your vehicle that } \\
\text { improved your miles per gallon (mpg) by } \mathbf{4 0 \%}\end{array}$ & $43 \%$ \\
\hline $\begin{array}{l}\text { Or, pay an additional } \mathbf{\$ 4 , 0 0 0} \text { to buy a plug-in hybrid version that could travel } \\
\text { up to 20 miles per day on its battery only, which would be recharged by the } \\
\text { wall socket with electricity at the cost of less than \$1 per gallon gasoline } \\
\text { equivalent, and would improve your miles per gallon (mpg) by 40\% }\end{array}$ & $26 \%$ \\
\hline Neither/Would not purchase a hybrid vehicle & $27 \%$ \\
\hline Don't know & $5 \%$ \\
\hline
\end{tabular}

Table 27. June 2006 Question 2: Willingness to Purchase a Hybrid Vehicle

\section{Source:}

ORC for NREL (2006), Study No. 715238, N=963.

Note: Only respondents who did not respond, "Don't drive" in question 1 were asked question 2. 


\subsection{April 2006 Type of Housing}

In April 2006 the majority of households (76\%) reported living in single-family homes. The expectation is that a single-family home could more easily allow for a specific location where a PEV could be plugged in.

\begin{tabular}{|l|r|}
\hline In which type of housing do you live? & Percent of Responses \\
\hline Single-family detached & $67 \%$ \\
\hline Multi-family unit, such as an apartment or condo & $17 \%$ \\
\hline Single-family attached, such as a duplex & $9 \%$ \\
\hline Mobile home & $5 \%$ \\
\hline Don't know & $2 \%$ \\
\hline
\end{tabular}

Table 28. April 2006 Question 1: Type of Housing

\section{Source:}

ORC for NREL (2006), Study No. 715168, N=1,000. 


\subsection{April 2006 Parking Location and Electricity Availability}

In April 2006 the majority of households (76\%) reported parking their cars in garages, carports, or driveways that could represent unique parking places for vehicles owned by the household. Fifty-seven percent of households reported parking their vehicles near available electrical outlets.

\begin{tabular}{|l|r|}
\hline $\begin{array}{l}\text { Which of these situations BEST describes where the vehicle you put the most } \\
\text { miles on in a year is located when it is parked at night? }\end{array}$ & $\begin{array}{r}\text { Percent of } \\
\text { Responses }\end{array}$ \\
\hline In a driveway & $36 \%$ \\
\hline In an attached garage & $26 \%$ \\
\hline In an unattached garage & $9 \%$ \\
\hline On the street, in front of or behind your residence & $9 \%$ \\
\hline In a parking lot for the use of residents of your housing complex & $8 \%$ \\
\hline In a carport & $5 \%$ \\
\hline Or, somewhere else & $1 \%$ \\
\hline Do not own a vehicle & $5 \%$ \\
\hline Don't know & $1 \%$ \\
\hline
\end{tabular}

Table 29. April 2006 Question 2A: Locations Where Vehicles are Parked

Source:

ORC for NREL (2006), Study No. 715168, N=507.

\begin{tabular}{|l|r|}
\hline $\begin{array}{l}\text { Based on where you can park this vehicle, could you consistently park it near } \\
\text { an existing electrical outlet so that on MOST days it could be plugged in? }\end{array}$ & $\begin{array}{r}\text { Percent of } \\
\text { Responses }\end{array}$ \\
\hline Yes & $57 \%$ \\
\hline No & $42 \%$ \\
\hline Don't know & $2 \%$ \\
\hline
\end{tabular}

Table 30. April 2006 Question 3A: Availability of Electrical Outlet Where Vehicle is Parked

\section{Source:}

ORC for NREL (2006), Study No. 715168, N=480.

Note: Only respondents who did not answer "Do not own a vehicle" to question 2A were asked question $3 \mathrm{~A}$. 


\subsection{April 2006 Awareness of PHEVs and Household Fit}

In April 2006 77\% of respondents reported having previously heard of PHEVs. Fifty-six percent of respondents agreed that PHEVs could be a good idea for their households.

\begin{tabular}{|l|r|}
\hline $\begin{array}{l}\text { The hybrid vehicles for sale today get all their energy from gasoline and electric } \\
\text { batteries. Another type of hybrid can get its energy from both gasoline and from } \\
\text { plugging into an electrical outlet. These are called plug-in hybrid vehicles. Have } \\
\text { you ever heard of this kind of hybrid before? }\end{array}$ & $\begin{array}{r}\text { Percent of } \\
\text { Responses }\end{array}$ \\
\hline Yes & $77 \%$ \\
\hline No & $23 \%$ \\
\hline Don't know & $1 \%$ \\
\hline
\end{tabular}

Table 31. April 2006 Question 2B: Awareness of PHEVs

Source:

ORC for NREL (2006), Study No. 715168, N=493.

\begin{tabular}{|l|r|}
\hline $\begin{array}{l}\text { Do you think that a vehicle that could take energy from a standard electric plug } \\
\text { and from a gasoline pump would be a good idea for your household? }\end{array}$ & $\begin{array}{r}\text { Percent of } \\
\text { Responses }\end{array}$ \\
\hline Yes & $56 \%$ \\
\hline No & $32 \%$ \\
\hline Don't know & $12 \%$ \\
\hline
\end{tabular}

Table 32. April 2006 question 3B: Opinion of PHEVs

\section{Source:}

ORC for NREL (2006), Study No. 715168, N=493. 


\subsection{July 2013 Plug-in Electric Vehicle Awareness and Exposure}

In July $201347 \%$ of respondents were able to name a specific PEV make and model. The Chevrolet Volt was most often named. The second most common model named was the Toyota Prius, which was also in the marketplace at the time of the study as an HEV that could not charge its battery by being plugged in. If any of the respondents thought of the HEV version of the Toyota Prius as a PEV, the results overstate the percentage of the population who could name a PEV. In total, $14 \%$ of the respondents reported having sat in and/or driven a PEV.

\begin{tabular}{|l|r|}
\hline $\begin{array}{l}\text { Can you name any PLUG-IN electric vehicles? Please } \\
\text { name as many as you can. }\end{array}$ & $\begin{array}{r}\text { Percent of } \\
\text { Responses }\end{array}$ \\
\hline Chevrolet Volt & $23 \%$ \\
\hline Toyota Prius Plug-in & $20 \%$ \\
\hline Nissan Leaf & $13 \%$ \\
\hline Tesla Model S & $6 \%$ \\
\hline Ford Fusion Energi & $3 \%$ \\
\hline Ford C-MAX Energi & $1 \%$ \\
\hline Other & $12 \%$ \\
\hline Don't know/none & $53 \%$ \\
\hline
\end{tabular}

Table 33. July 2013 Question 1: Naming PEVs

\section{Source:}

ORC for NREL (2013), Study No. 722269/74460, N=1,000.

\begin{tabular}{|l|r|}
\hline $\begin{array}{l}\text { Have you ever ridden in or driven a plug-in electric } \\
\text { vehicle? Would you say... }\end{array}$ & $\begin{array}{r}\text { Percent of } \\
\text { Responses }\end{array}$ \\
\hline Have ridden in a PEV & $11 \%$ \\
\hline Have driven a PEV & $6 \%$ \\
\hline Not ridden or driven & $85 \%$ \\
\hline Don't know & $1 \%$ \\
\hline
\end{tabular}

Table 34. July 2013 Question 2: Exposure to PEVs

\section{Source:}

ORC for NREL (2013), Study No. 722269/74460, N=1,000. 


\subsection{July 2013 PEVs versus Conventional Gasoline Vehicles}

In July $201347 \%$ of respondents believed PEVs were just as good as or better than conventional gasoline vehicles. Roughly one-third of the respondents thought that PEVs were not as good as conventional gasoline vehicles. The $14 \%$ of respondents who had earlier reported having been in PEVs were classified as PEV exposed (136 respondents). The 85\% of respondents who had not been in PEVs were classified as PEV unexposed (864 respondents). The PEV exposed percentage of the respondents was more likely to have an opinion of PEVs, more likely to view PEVs as just as good as or better than gasoline vehicles, and were slightly less likely to view PEVs as being not as good as gasoline vehicles. The results of this comparison do not confirm that the exposure impacted the respondents' views, because no information is available about the respondents' perceptions before they were in PEVs.

\begin{tabular}{|l|r|}
\hline $\begin{array}{l}\text { What is your opinion of plug-in electric } \\
\text { vehicles? Would you say they are... }\end{array}$ & $\begin{array}{r}\text { Percent of } \\
\text { Responses }\end{array}$ \\
\hline Better than gas vehicles & $16 \%$ \\
\hline Just as good as gas vehicles & $32 \%$ \\
\hline Not as good as gas vehicles & $32 \%$ \\
\hline Don't know & $21 \%$ \\
\hline
\end{tabular}

Table 35. July 2013 Question 3: Opinion of PEVs

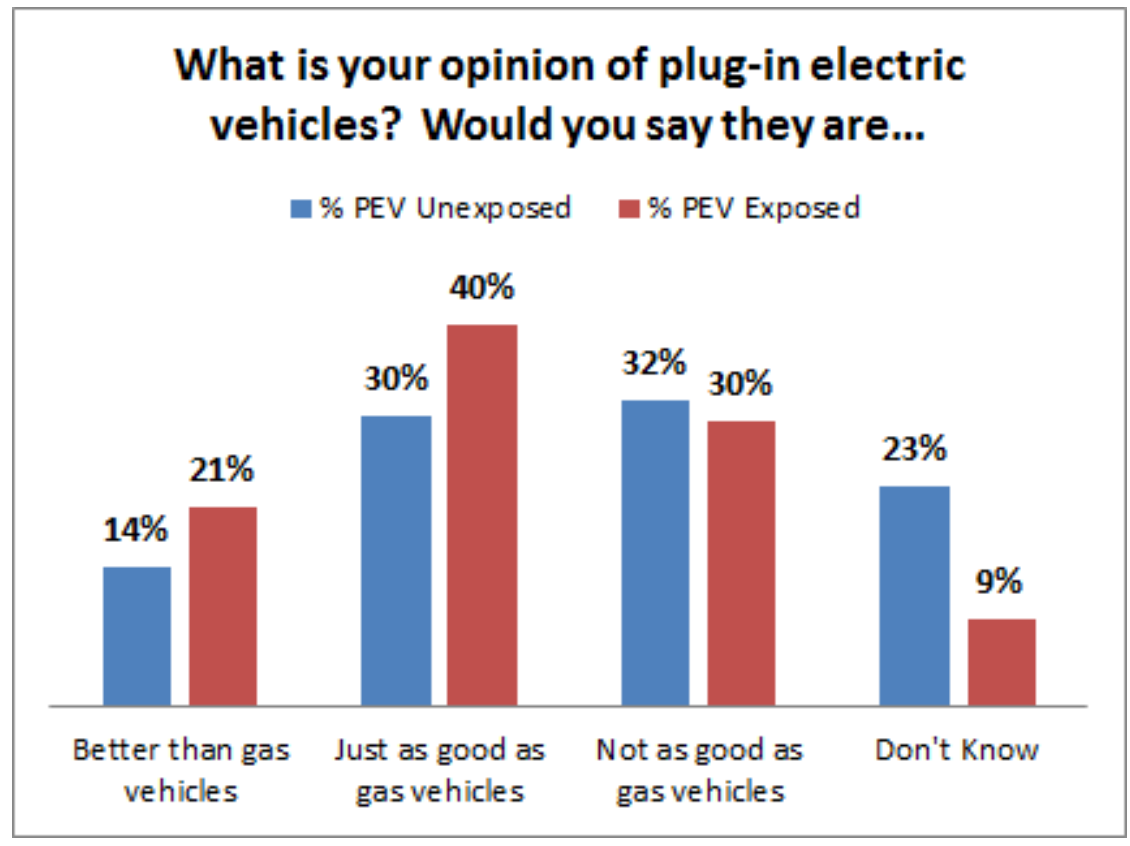

Figure 17. July 2013 Question 3: PEV Exposure and PEV Opinions

\section{Source:}

ORC for NREL (2013), Study No. 722269/74460, N=1,000. 


\subsection{July 2013 Interest in Wireless Charging}

The July 2013 study captured sentiments toward an advanced technology that would allow PEVs to charge wirelessly. Overall, $50 \%$ of the population stated the wireless charging capability would increase their interest in PEVs. Nine percent of the respondents stated they would be more interested in PEVs after having stated that PEVs were not as good as gasoline vehicles earlier in question 3. Forty-six percent of respondents were willing to pay an incremental cost for a vehicle that is capable of wireless charging. The respondents reported a wide range of incremental costs they were willing to incur. Forty-eight percent of those who reported an incremental cost would be willing to pay just $\$ 1,000$ or less.

Technical advances are making it possible to charge plug-in electric vehicles without physically plugging them in. If plug-in electric vehicles available for purchase had this capability, would you be more interested in purchasing a plug-in electric vehicle?

Percent of Responses

\begin{tabular}{|l|r|}
\hline Yes & $50 \%$ \\
\hline No & $45 \%$ \\
\hline Don't know & $4 \%$ \\
\hline
\end{tabular}

Table 36. July 2013 Question 4: Interest in Wireless Charging

\section{Source:}

ORC for NREL (2013), Study No. 722269/74460, N=1,000.

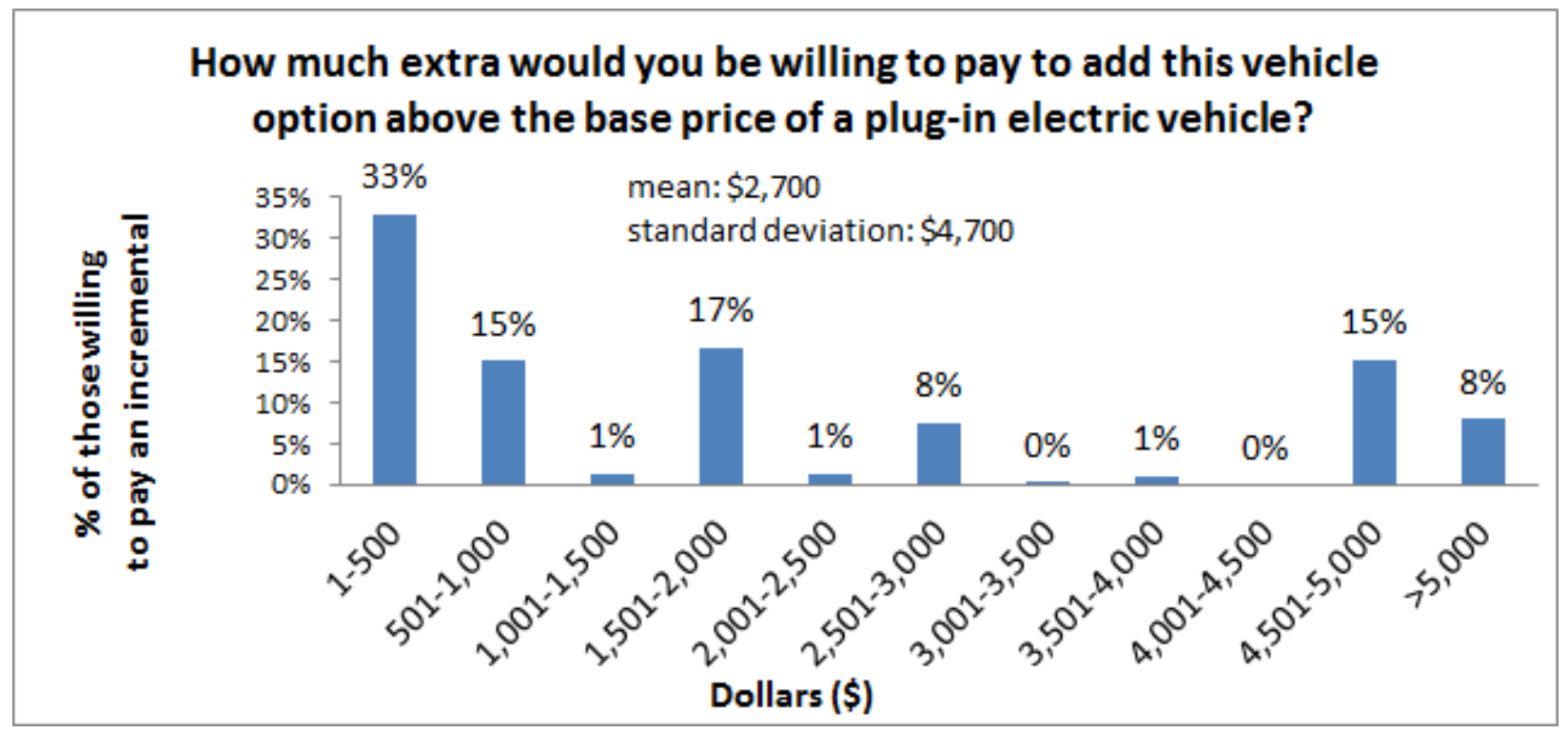

Figure 18. July 2013 question 5: Willingness to pay more for PEVs

Source:

ORC for NREL (2013), Study No. 722269/74460, N=461.

Note: Incremental cost values were provided by $46 \%$ of respondents. 


\section{Willingness to Pay for Efficiency}

\section{Contents}

5.1 Willingness To Pay for Efficiency Overview ………..................................................46

5.2 June 2011 Incremental Cost Willing To Pay for Increased Fuel Efficiency .....................47

5.3 June 2011 Fuel Cost Savings Required To Pay More for Higher Fuel Economy............48

5.4 April 2012 Incremental Cost Willing To Pay for More Efficient Vehicle (Revised Amounts)

5.5 April 2012 Fuel Cost Savings Required To Pay More for Higher Fuel Economy (Revised Amounts)....

5.6 January 2013 Likelihood of Purchasing a New versus a Used Vehicle ...........................51

5.7 January 2013 Fuel Cost Savings Required To Pay More for Higher Fuel Economy (New versus Used Vehicle Purchasers) .....................................................................52

5.8 Implied Payback Periods for Willingness To Pay More for Higher Fuel Economy ........53 


\subsection{Willingness To Pay for Efficiency Overview}

Highly efficient advanced vehicle technologies often carry significant incremental costs over the conventional vehicles available in the market. These incremental upfront costs can be offset by the fuel cost savings the driver will experience over the vehicle's lifetime. A series of questions was designed to help understand the extent to which consumers are willing to incur the upfront vehicle cost if they will experience fuel cost savings.

June 2011 and April 2012 studies first asked respondents to provide the additional amount they would be willing to spend on a vehicle that would save them a specific predefined amount in annual fuel costs. The studies then followed up by asking respondents to provide the annual fuel cost savings they would require in order to pay a specified higher upfront cost for the vehicle.

Under the first framing, respondents who provided a value were willing to spend an average of $\$ 1,200$ and $\$ 2,300$ for promised annual savings of $\$ 400$ and $\$ 600$, respectively. Respondents who provided a value were willing to incur a specified additional cost of $\$ 1,200$ or $\$ 1,900$ if they could achieve annual fuel cost savings on average of $\$ 750$ and $\$ 1,500$, respectively.

A similar January 2013 study asked respondents to provide an annual fuel cost savings for a specified upfront increased vehicle cost. The study included a question that classified $46 \%$ of respondents as new car purchasers and $49 \%$ as used car purchasers. The study did not show a difference between new and used car purchasers when considering willingness to incur upfront costs. Of respondents who provided a value, both cohorts were willing to spend a specified additional cost of $\$ 1,500$ if they could achieve annual fuel cost savings on average of $\$ 1,100$.

The questions in this section were designed to force the respondents to calculate an implicit payback period while determining what upfront costs they were willing to pay or what fuel cost savings they would require. Undiscounted payback periods calculated by dividing the upfront incremental costs by the annual fuel cost savings show that the period would need to be 1 to 1.5 years for $50 \%$ of respondents to state a willingness to incur the upfront cost.

These studies show considerable variability across the population about a willingness to incur an upfront cost to save annual fuel costs over a vehicle's life. Although a percentage of the population is willing to wait longer to recoup upfront costs, a majority of respondents require a relatively quick payback to be willing to spend more upfront. 


\subsection{June 2011 Incremental Cost Willing To Pay for Increased Fuel Efficiency}

In June 2011 respondents were asked, "Consider the next vehicle you plan to purchase or lease. Suppose an optional engine were available, just as good in all respects as the engine you are considering buying, but more fuel efficient. If the engine would save $\$ 400$ in fuel each year how much EXTRA would you be willing to spend for the vehicle?"

Respondents were willing to spend an extra $\$ 1,200$ on average for the vehicle that would save them $\$ 400$ annually in fuel costs.

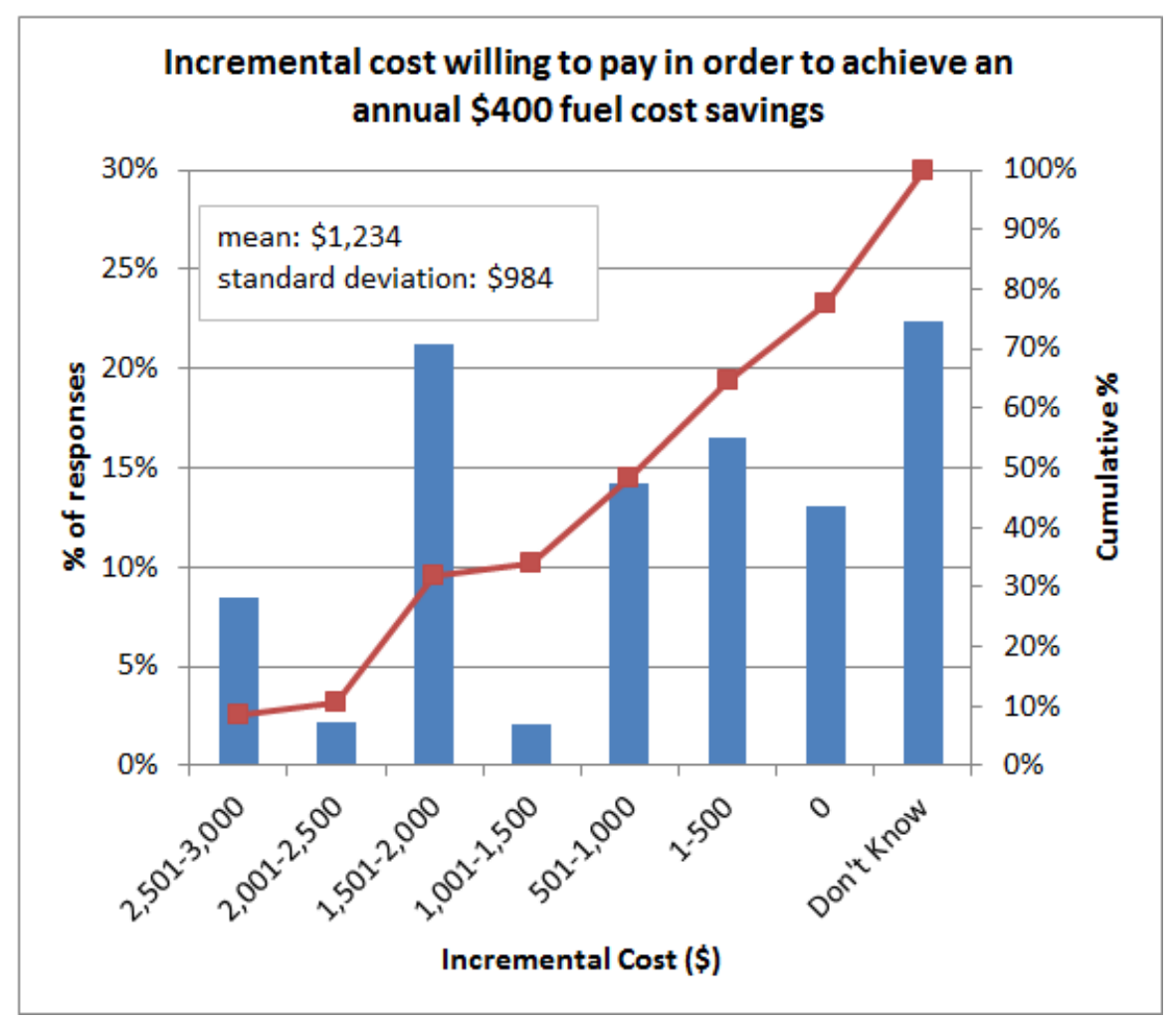

Figure 19. June 2011 question 1: Incremental cost willing to pay for increased fuel efficiency

\section{Source:}

ORC for NREL (2011), Study No. 720229, N=506.

Note: Only respondents who provided a specific value were included in mean and standard deviation calculations. 


\subsection{June 2011 Fuel Cost Savings Required To Pay More for Higher Fuel Economy}

In June 2011 respondents were asked, "Consider the next vehicle you plan to purchase or lease. Suppose an optional engine were available, just as good in all respects as the engine you are considering buying, but more fuel efficient. If the engine cost $\$ 1,200$ more, how much would it have to save you EACH YEAR in fuel costs before you would be willing to buy it?" Respondents on average would require a $\$ 750$ annual fuel savings to be willing to purchase a more efficient vehicle that would be $\$ 1,200$ more expensive.

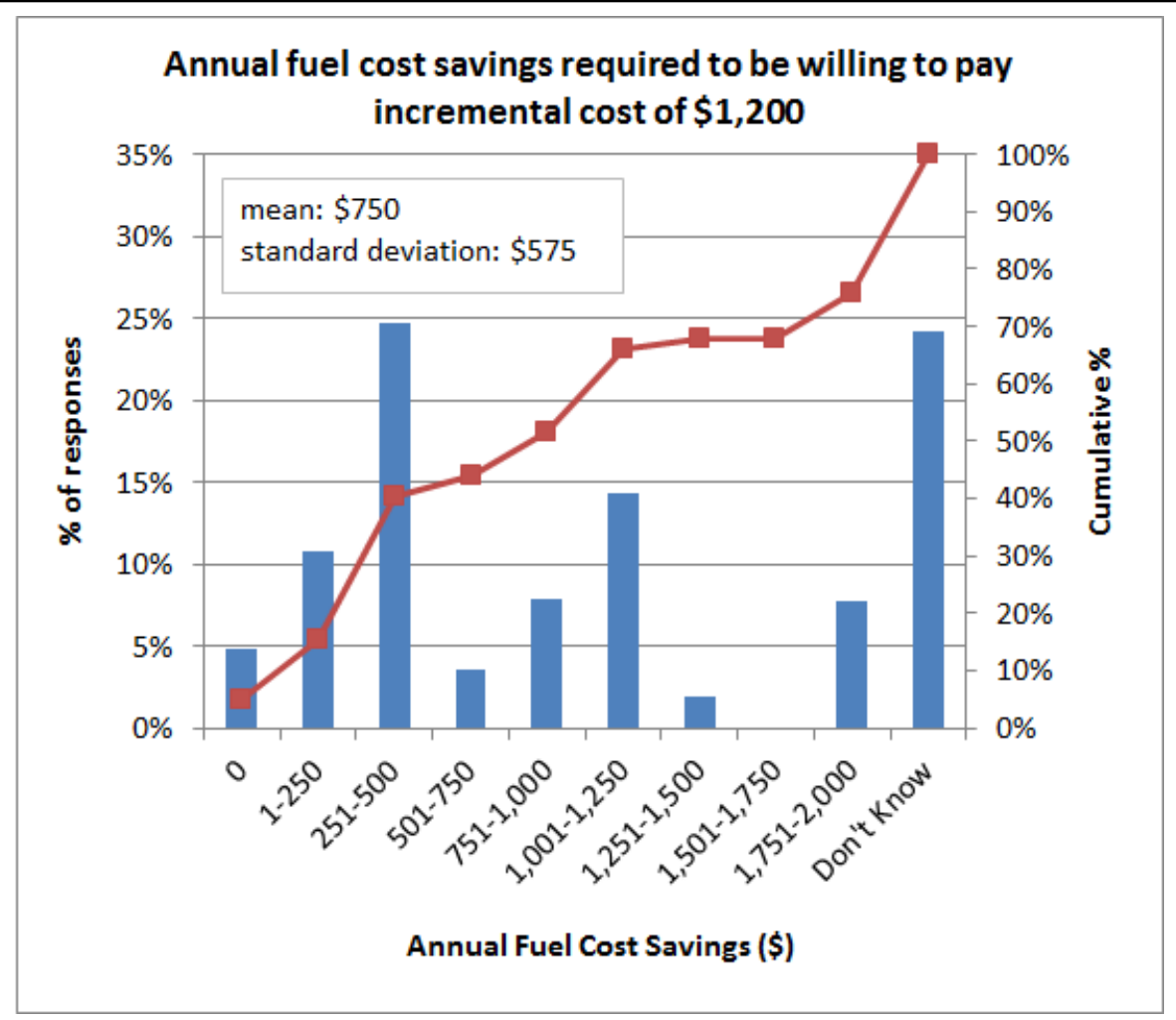

Figure 20. June 2011 question 2: Fuel cost savings required to pay more for higher efficiency

\section{Source:}

ORC for NREL (2011), Study No. 720229, N=494.

Note: Only respondents who provided a specific value were included in mean and standard deviation calculations. 


\subsection{April 2012 Incremental Cost Willing To Pay for More Efficient Vehicle (Revised Amounts)}

In April 2012 respondents were asked, "Think about the next vehicle you plan to buy or lease. Suppose an optional engine were available, just as good in every way as the engine you are planning to buy, but with better fuel economy. If the optional engine would save $\$ 600$ in fuel each year how much EXTRA would you be willing to pay for the vehicle?"

Respondents were willing to spend an extra $\$ 2,300$ on average for a vehicle that would save them $\$ 600$ annually.

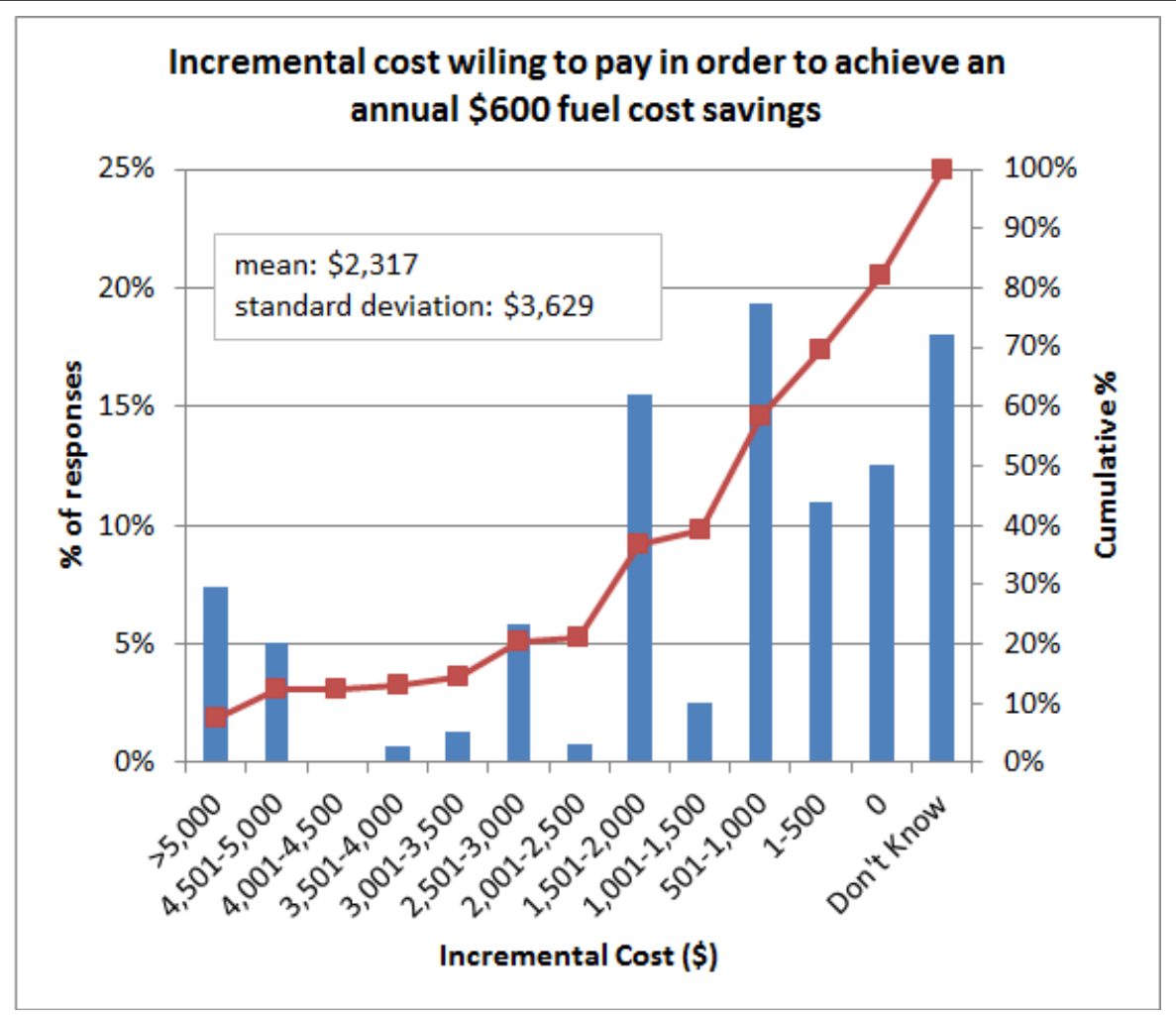

Figure 21. April 2012 question 1: Incremental cost willing to pay for increased fuel efficiency

\section{Source:}

ORC for NREL (2012), Study No. 721159, N=506.

Note: Only respondents who provided a specific value were included in mean and standard deviation calculations. 


\subsection{April 2012 Fuel Cost Savings Required To Pay More for Higher Fuel Economy (Revised Amounts)}

In April 2012 respondents were asked, "Think about the next vehicle you plan to buy or lease. Suppose an optional engine were available, just as good in every way as the engine you are planning to buy, but with better fuel economy. If the engine cost $\$ 1,900$ more, how much would it have to save you EACH YEAR in fuel costs before you would be willing to buy it?" Respondents on average would require nearly $\$ 1,500$ in annual fuel savings to be willing to purchase a more efficient vehicle that would be $\$ 1,900$ more expensive.

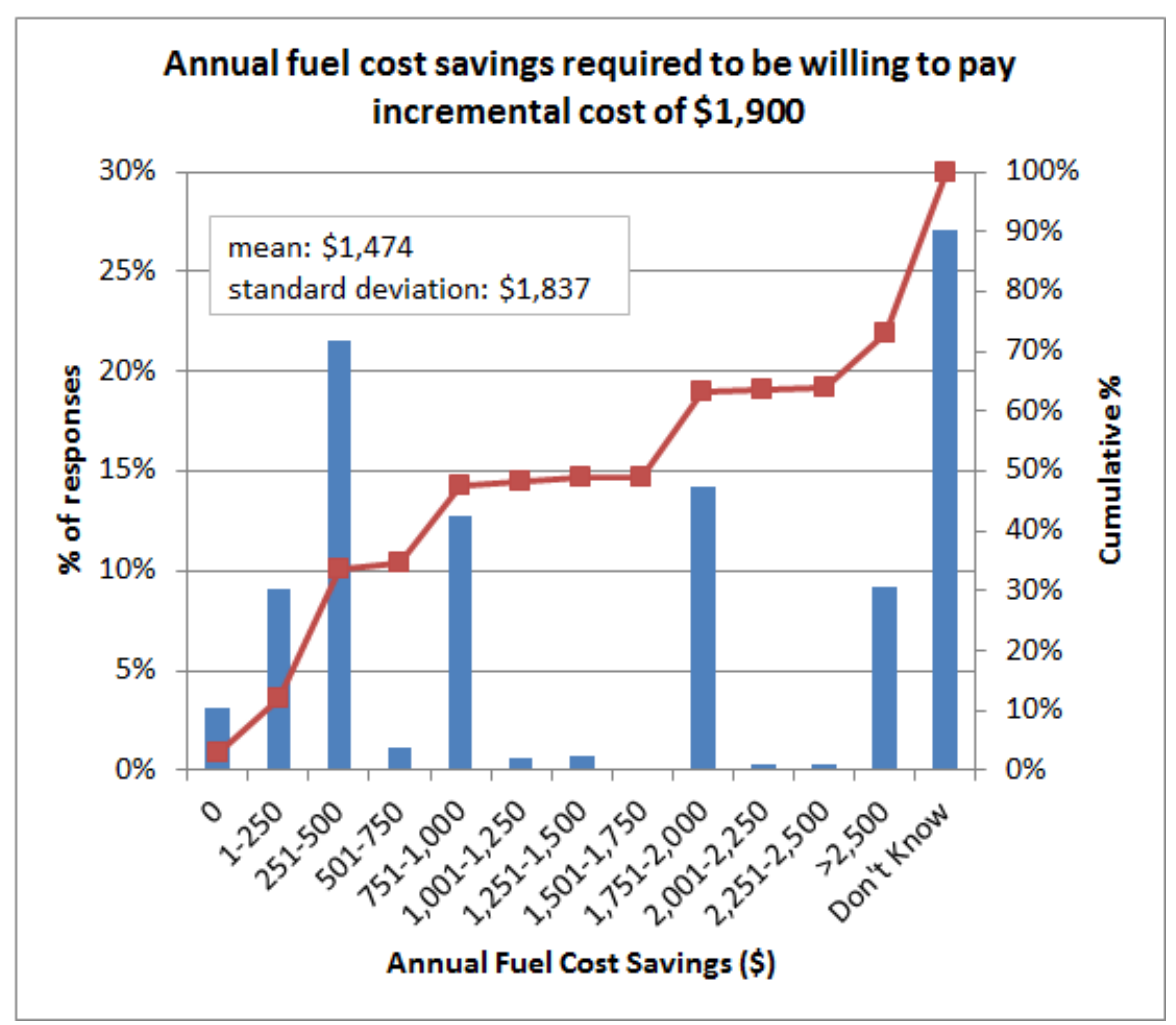

Figure 22. April 2012 question 2: Fuel cost savings required to pay more for higher efficiency

\section{Source:}

ORC for NREL (2012), Study No. 721159, N=494.

Note: Only respondents who provided a specific value were included in mean and standard deviation calculations. 


\subsection{January 2013 Likelihood of Purchasing a New versus a Used Vehicle}

In January 2013 respondents were classified as new car purchasers or used car purchasers to determine if their new or used car preferences may correlate with their willingness to pay more for higher vehicle fuel economy. Respondents were classified as new car purchasers if they answered that they "definitely," "probably," or "maybe" would buy new vehicles.

Respondents who said they were "not very likely" or "not at all likely" to buy new vehicles were classified as used car purchasers. Following this classification, $46 \%$ of respondents were new car purchasers, and $49 \%$ were used car purchasers.

\begin{tabular}{|l|r|}
\hline $\begin{array}{l}\text { When you purchase or lease your next vehicle, how } \\
\text { likely is it to be a brand new vehicle? Would you say... }\end{array}$ & $\begin{array}{r}\text { Percent of } \\
\text { Responses }\end{array}$ \\
\hline Definitely-you will always buy a new vehicle & $15 \%$ \\
\hline Probably-you will usually buy a new vehicle & $16 \%$ \\
\hline Maybe-you will sometimes buy a new vehicle & $15 \%$ \\
\hline Not very likely-you will rarely buy a new vehicle & $23 \%$ \\
\hline Not at all likely-you will never buy a new vehicle & $26 \%$ \\
\hline Do not expect to buy or lease a vehicle & $4 \%$ \\
\hline Don't know/No response & $0 \%$ \\
\hline
\end{tabular}

Table 37. January 2013 Question 1: Likelihood of Purchasing a New versus a Used Vehicle

\section{Source:}

ORC for NREL (2013), Study No. 722038/74403, N=1,000. 


\subsection{January 2013 Fuel Cost Savings Required To Pay More for Higher Fuel Economy (New versus Used Vehicle Purchasers)}

In January 2013 respondents were asked, "Suppose you are buying your next (used)/(new) vehicle and assume that there are two optional engines on the same vehicle that offer the same performance and reliability. One costs $\$ 1,500$ more but gets much better fuel economy. What is the minimum dollar amount the better fuel economy engine would have to SAVE in gas each YEAR for you to pay the additional \$1,500?"

New car purchasers and used car purchasers would, on average, require a $\$ 1,100$ annual fuel cost savings to incur an upfront incremental cost of $\$ 1,500$ for purchasing a more efficient vehicle.

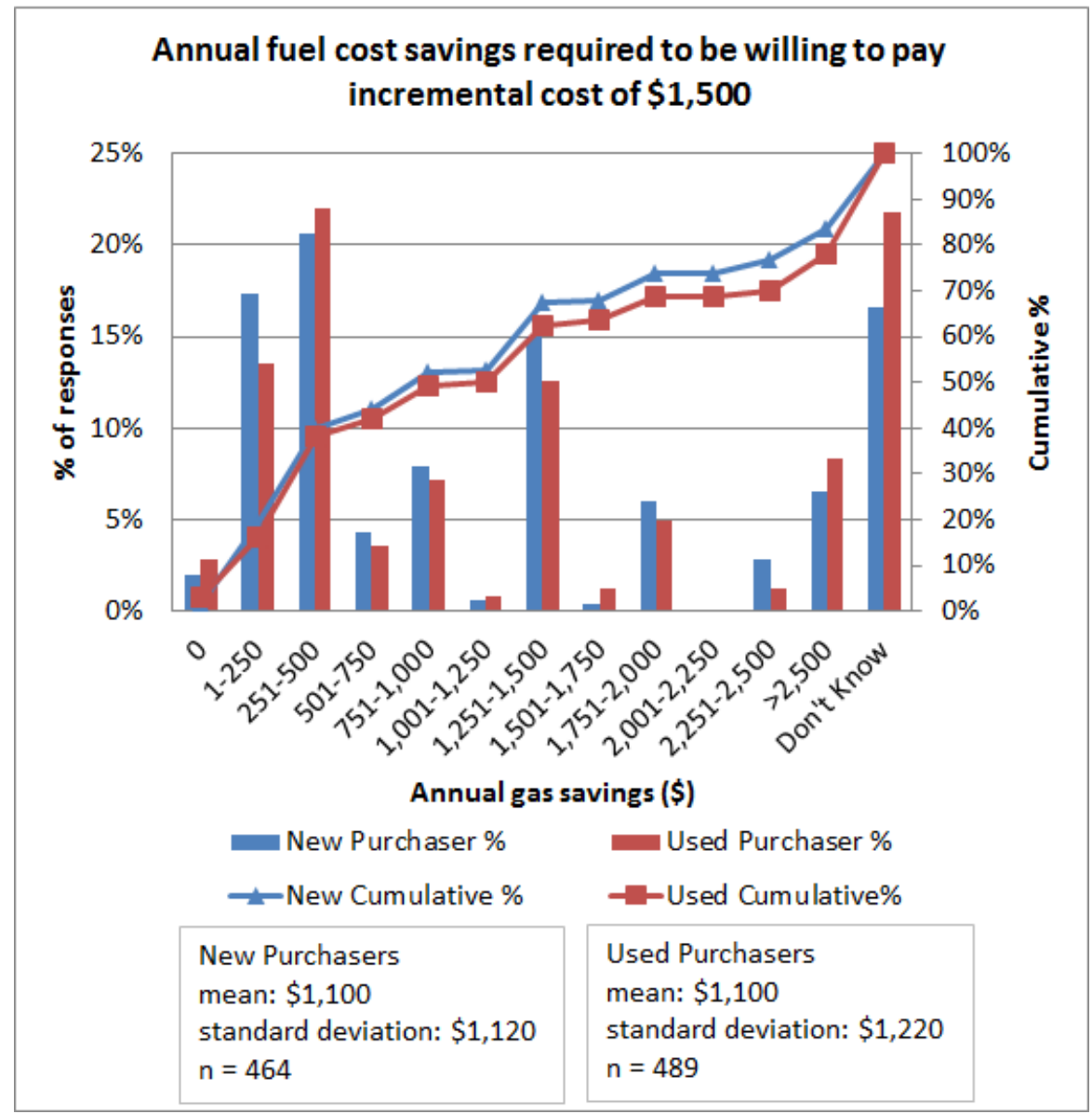

Figure 23. January 2013: Fuel cost savings required to pay more for higher efficiency

\section{Source:}

ORC for NREL (2013), Study No. 722038/74403, N=1,000.

Notes: Respondents who answered, "Do not expect to buy or lease a vehicle" or "Don't know/no response" in question 1 were excluded from question 2. Only respondents who provided a specific value were included in mean and standard deviation calculations. 


\subsection{Implied Payback Periods for Willingness To Pay More for Higher Fuel Economy}

The results of each question investigating willingness to pay an upfront cost for a more fuelefficient vehicle can be converted to an implied undiscounted payback period for each respondent by dividing the upfront incremental cost (provided in the question or in the response) by the annual fuel cost savings (also provided either in the question or in the response). The compilation of these studies shows that roughly $25 \%$ of respondents report a willingness to pay an upfront cost if the undiscounted payback period is 3 years or longer. The undiscounted payback period would need to be 1 to 1.5 years for $50 \%$ of respondents to report a willingness to incur the upfront cost.

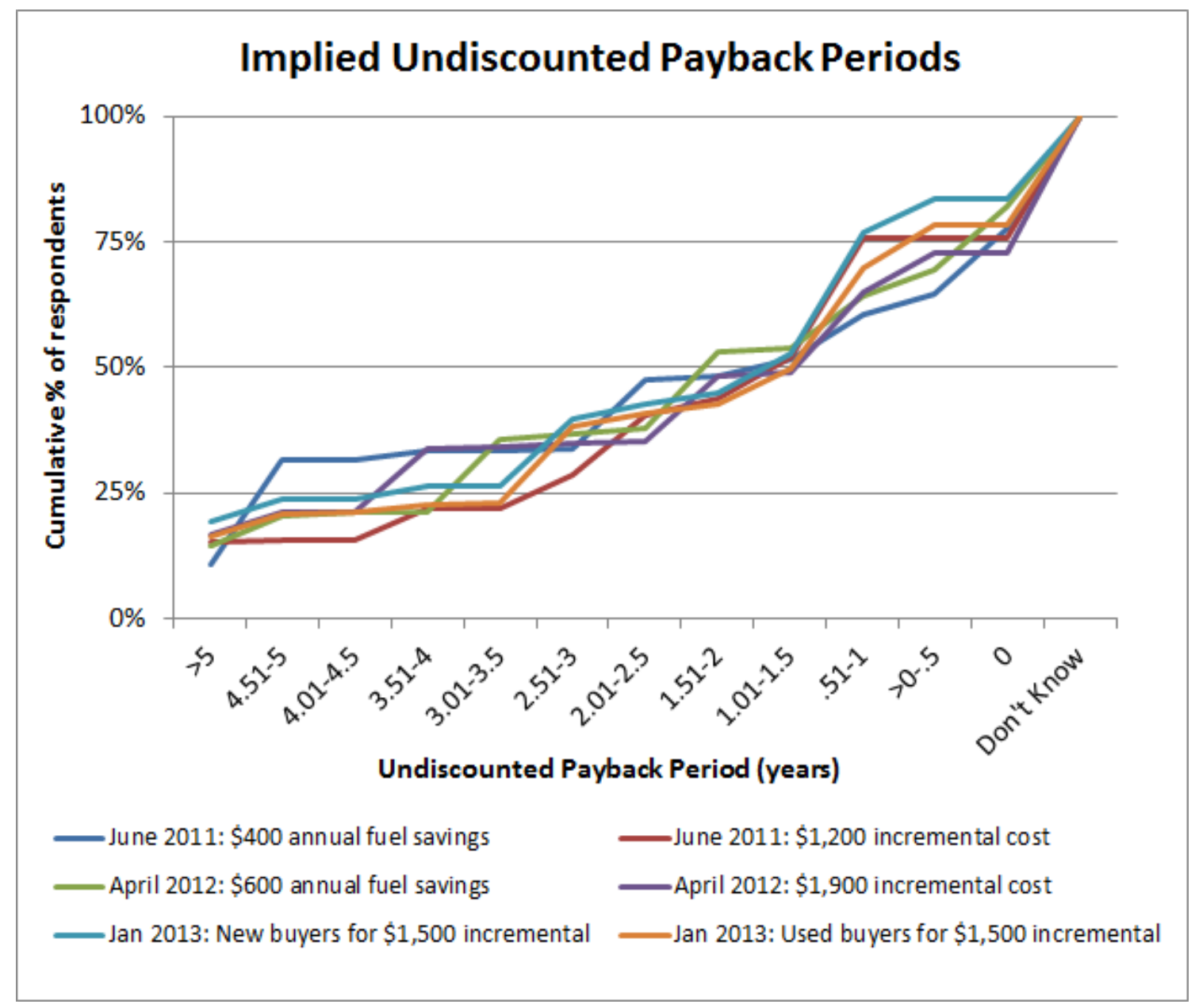

Figure 24. Compiled results: Implied undiscounted payback periods

\section{Sources:}

For 2011: ORC for NREL (2011), Study No. 720229, N=1,000.

For 2012: ORC for NREL (2012), Study No. 721159, N=1,000.

For 2013: ORC for NREL (2013), Study No. 722038/74403, N=1,000. 


\section{References}

DOE. 2008. "2008 Ratings Changes." U.S. Department of Energy, accessed August 7, 2015: http://www.fueleconomy.gov/feg/ratings2008.shtml\#.

DOE. 2011. "Learn about the New Label." U.S. Department of Energy, accessed August 7, 2015: http://www.fueleconomy.gov/feg/Find.do?action=bt1.

DOE. 2014. "U.S. Alternative Fueling Stations by Type." U.S. Department of Energy, accessed August 7, 2015: http://www.afdc.energy.gov/data/10332.

DOE. 2015. "Light-Duty AFV, HEV, and Diesel Model Offerings, by Fuel Type." U.S. Department of Energy, accessed August 7, 2015: http://www.afdc.energy.gov/data/10303.

Kane, M.P., and Wasi, N. 2013. The Structure of Consumer Taste Heterogeneity in Revealed vs. Stated Preference Data. Oxford, U.K.: University of Oxford. www.nuffield.ox.ac.uk/economics/papers/2013/SP_RP_data\%20-\%20Final.pdf.

Kubik, M. (2006). Consumer Views on Transportation and Energy (Third Edition). NREL/TP620-39047. Golden, CO: National Renewable Energy Laboratory. Accessed September 24, 2014: http://www.nrel.gov/docs/fy06osti/39047.pdf.

Washington Post. 2006. "President Bush's State of the Union Address." Washington Post, accessed August 7, 2015: http://www.washingtonpost.com/wpdyn/content/article/2006/01/31/AR2006013101468.html. 